\title{
Capital Markets and Capital Allocation: Implications for Economies of Transition
}

By: Artyom Durnev, Kan Li, Randall Morck, and Bernard Yeung

William Davidson Working Paper Number 417

October 2003 
First Draft, November $10^{\text {th }} 2000$

This draft, Oct $2^{\text {nd }} 2003$

Comments Welcome

\title{
Capital Markets and Capital Allocation: Implications for Economies in Transition
}

\author{
Art Durnev*, Kan Li**, Randall Morck, and Bernard Yeung**
}

JEL classification: G3, K2, O4

Keywords: capital markets, institutional environment, ownership structure, growth

\footnotetext{
* Assistant Professor of Finance, University of Miami, Coral Gables, Florida, 33134. E-mail: adurnev@miami.edu. Phone: (305) 284-8285.

** Doctoral student, University of Alberta School of Business, Edmonton, Alberta, Canada T6G 2R6.

* Stephen A. Jarislowsky Distinguished Professor of Finance, University of Alberta School of Business, Edmonton, Canada T6G 2R6. E-mail: randall.morck@ualberta.ca. Phone: (780) 492-5683.

** Abraham Krasnoff Professor of International Business, Professor of Economics and Professor of Management, Stern School of Business, New York University, New York NY 10012. E-mail: byeung@stern.nyu.edu. Phone: (212) 998-0425.
}

We are grateful for the comments of the participants in the WDI-CPER Moscow Conference on Emerging Markets in June 2000. Also, we are grateful for the helpful comments of Paul Wachtel, the editor, Erik Berglof, and the referee. 


\begin{abstract}
It is now well established that a sounder financial system is associated with faster economic growth. Recent research that examines the details of this connection has important implications for economies in transition. Stock prices in rich countries move in highly idiosyncratic ways that convey information about changes in firms' marginal value of investment. This information is important because it facilitates the rapid flow of capital to its highest value uses. In contrast, stock prices in low-income countries tend to move up and down en masse, and thus are of scant use for capital allocation. Stock return asynchronicity is highly correlated with the strength of private property rights in general - and shareholder rights in particular. Many countries have avoided protecting these rights for many decades. In light of the research we survey, the persistence of such policies requires explanation. Another strand of new papers offers insights. In many countries an elite (often the descendants of industrial barons who grew rich off political "connections" during early stages of development) controls most large corporations through "pyramidal" corporate groups. This corporate control gives the elite vast rent-seeking powers, which it uses to limit outsiders' property rights and outsiders' access to capital. The latter is accomplished by keeping the stock market and financial system from functioning well. The initial stages of this process of "economic entrenchment" may be under way in many transition economies. Economic openness may limit this sort of "economic entrenchment", and thus contribute to institutional reform and economic growth.
\end{abstract}




\section{Introduction}

Emerging economies are the most important phenomenon in contemporary economics. Their transition to affluence is itself important because it directly affects the well being of more than half of the world's population. But this pivotal transition also provides a magnificent chance for economists to understand better how our economies work.

The contrast between the performance of the twentieth century's command and market economies validates Hayek's (1945) prophecy. Hayek reasoned that a market economy is continuously in flux, and that understanding these continual changes is a daunting informationprocessing task. This information-processing capability is critical to continually reallocating resources to their best uses in such an ever-changing environment. This reallocation requires coordination of the economic actions of huge numbers of people. Hayek concluded that such a massive information processing and coordination exercise is beyond the ability of even the most skilled planners using the most pervasive state surveillance and control apparatus. Such an effort, he argued, is possible only in a system of decentralized decision-making relying on market price signals within a structure of properly aligned economic incentives and private property rights - that is, in a free-market economy.

The essence of resource allocation in a market economy is that more resources should flow to activities with higher payoff prospects. Firms, established or upstart, with better payoff prospects obtain financing and consequently expand their physical investment, compete more successfully to procure raw materials and labor, and ultimately expand production. Firms with poorer payoffs experience the opposite: they do not obtain as much capital and consequently shrink - at least relatively. 
Capital markets are central to how free-market economies perform this information processing and coordination exercise - they are the device charged with the responsibility. A large theoretical and empirical literature documents capital markets' positive contribution to economic growth. For excellent surveys, see Levine (2000 and 1997). This literature points out four important roles for capital markets: mobilizing savings, facilitating risk reduction (crosssectionally and intertemporally), monitoring managerial behavior, and processing information.

In this paper, we first focus on the information-processing role of asset prices - and of the institutional environment in which prices are formed. We survey some recent results that identify a strong link between institutional integrity and equity price behavior: In institutional environments in which the government better honors property rights in general, and investors' property rights over their investments in particular, equity prices display substantially more firmspecific return variation. When the institutional environment does not protect these property rights, equity returns are highly synchronous and lack information contents. We further survey evidence that in economies where firm-specific stock return variation is higher, investment decisions are more efficient.

One possible interpretation of this evidence is that institutional integrity, by which we mean strong general property rights protection and strong protection for investors' rights, fosters the development of informed risk arbitrage, which leads to more informed asset pricing. More informed asset pricing, in turn, leads to better corporate governance, which is reflected in higher quality (more value creating) investment decisions.

The research we describe is, for the most part, about equity prices. Empirical studies concentrate on stock markets, perhaps because data are more readily available. Nonetheless, we believe that the message is general. The cornerstone of a good institutional environment is 
government protection of property rights in general, and strong legal protection for the property rights of outside shareholders (and, more generally, claimants not directly controlling corporate actions). These institutions induce good corporate governance and discerning investment decisions, which in turn make stocks good investments. Dynamism in stock markets tends to spill over into the rest of the financial system. In contrast, weak institutional environments retard not only stock markets, but the financial system overall. For example, there is no reason that banks which are in the same poor institution environment could be exempted from the corporate governance problems that thwart other corporations' performance and do a good job in their business. Suffering from the same problems, banks cannot serve their intermediation role well. We discuss this point in greater detail below, linking up with established results on the relationship between poor corporate governance in banks.

The discussions suggest that stock return asynchronicity should be associated with better growth. The linkage stems from several sources. First, greater stock return asynchronicity is indicative of better property rights protection and thus greater capital market development which positively affects growth. Second, greater stock return synchronicity per se indicates greater impounding of information in the device (capital markets) that allocates resources. Using a cross country panel data regression, we show that greater total growth and productivity growth are both linked to stock return asynchronicity, even after controlling for capital market development and good "rule of the law."

The results we surveyed and the new econometric results we obtained suggest a strong link between property rights protection for outside investors and the functionality of capital markets. Strengthening property rights in an economy in which they are weak is tantamount to redistributing property rights and thus re-distributing economic power. Even if this 
redistribution can be Pareto improving, the losers in this redistribution cannot expect to be fully compensated. Property rights redistributions are fundamentally political economy issues.

We therefore report another set of recent research results that address this issue. We find that countries with high concentration of wealth and control over corporate assets exhibit slower economic growth that can be attributed to the "economic entrenchment" of established interests. Countries in which established interests have a more extensive control over capital assets have greater entry barriers, and (notably) greater barriers against the inflow of foreign investment. Such barriers likely protect established interests at the expenses of possible upstarts.

Hence, we direct the readers' attention to the thorny political economy problem of building a good institutional environment. In a political economic framework, we argue that economic entrenchment, as a rent-seeking equilibrium, is the explanation for the lack of good property rights protection for investors and capital market development in many economies. "Economic entrenchment" is that rich elites are able to "influence" politicians - politicians do not implement good property rights policies to preserve the elites' economic interest. Using the political economy framework and relying on results obtained in economic history studies, we are able to describe the conditions that can lead to economic entrenchment: skew income distribution and transaction costs in rent-seeking both in favor of a few rich elites, low education level and poor social transparency. We believe that these conditions are prevalent in transition economies so that economic entrenchment is a real threat to them.

We believe that we have proposed an important research avenue to advance a better understood of economic transition. The line of attack we advocate includes: (i) recognizing the importance of capital market's functionality as a market economy's device to allocate resources, (ii) the functionality of capital market depends on rules and policies that protect investors' rights, 
(iii) the rules and policies, however, are determined as political economy outcomes reflecting the preferences of players and the players' variable rent-seeking ability to influence the outcome.

\section{Some Illustrations of Functional and Dysfunctional Stock Markets}

Our starting point is the information-processing role of asset prices, the dependence of this role on an economy's institutional features, and the importance of this role to the functionality of capital markets as capital allocators. It is useful to start with some anecdotal evidence to illustrate our points.

Figure I shows both the value of S\&P 500 and the value of Heinz' stock during the five trading days prior to Dec $7^{\text {th }} 1999$. Friday morning, Heinz's stock prices rise, but this rise parallels a similar rise in the S\&P500 index. Consequently, this price movement is not a signal of superior management at Heinz. In contrast, on Monday morning, Heinz stock rises while the S\&P index does not. This price increase does reflect favorably on the quality of Heinz management. Closer investigation confirms this. Heinz's share price previously sagged because investors judged the company uncompetitive. Heinz responded in early 1999 by revamping its operations, undertaking a serious restructuring effort called 'Operation Excel'. The company refocused, downsized, and achieved substantial savings. The improved and better than expected earnings report of December 1999 confirmed this improvement, leading to a surge in the company's share value. The follow up was the company could once again raise funds on attractive terms, and could therefore make plans to grow again (Wall Street Journal, December 7, 1999).

This story illustrates how a functioning equity market in the US works. When stock prices incorporate firm-specific information, the market can distinguish good firms from bad. 
The direct effect of this is that the market can channel financing towards good firms and away from problem firms. The indirect effect is that this transparency disciplines managerial behavior, leading either to appropriate adjustments of managerial behavior, or to takeover bids by outsiders who think they can manage the firm better than the incumbents.

Many emerging stock markets do not seem to work this way. On July $31^{\text {st }} 2001$, the Wall Street Journal reported that a Chinese company, Zhengzhou Baiwen, was on the brink of failure. Its debts were almost double the value of its assets, and its creditors were trying to liquidate the company. Yet, the company's stock was surging effervescently. The Wall Street Journal reported that, "investors continue to be mostly in the dark about the company, whose shares finished Friday at 76 cents, up $31 \%$ from a month ago and up 56\% from a year ago. Securities regulators say that with a dozen listed companies teetering on the edge of bankruptcy, news of Baiwen's woes could lead to a selling binge, undermining the government's plan to bail out its money-losing state sector by listing even more of it on domestic stock markets. ... [The authorities] have imposed a news blackout on Baiwen in the Chinese press, even as the company's stock surges and its market capitalization approaches $\$ 140$ million.”

Baiwen's stock, along with the stocks of several other insolvent companies, benefited from a general run-up in Chinese stocks, which many observers felt was 'primed' by government officials. The Chinese market failed to distinguish good stocks from bad ones. Baiwen, though bankrupt, was actually in a position to obtain new funds by issuing additional high priced equity. This story shows that firm-specific information is not reflected in stock prices. In this setting, the equity market is (hopefully) only a sideshow in resources allocation. 
Stories such as this, and they are by no means uncommon, raise legitimate concerns about whether or not stock markets in emerging economies are fulfilling constructive information-processing and resource allocation roles.

\section{A Paucity of Firm-Specific Information in Emerging Stock Markets}

\section{The Phenomenon}

Morck, Yeung and $\mathrm{Yu}(2000)$ decompose the variation in individual equity returns across countries. They show that in the US and most other rich county stock markets, substantial firmspecific information is capitalized into share prices, and stock returns are consequently highly asynchronous. In the US, as in Denmark, Ireland, and New Zealand, some shares advance and some decline on any given day. In contrast, share prices in emerging markets exhibit a high degree of synchronicity.

Morck, Yeung and Yu (2000) create a formal synchronicity index for each country $j$. To do this, they first regress a country's bi-weekly stock returns for all of 1995 , denoted $r_{i, j, t}$, on the contemporaneous domestic market return, $r_{m, j, t}$, and a world market factor (proxied for by the US market return, $r_{u s, j, t}$ ) converted into home currency using an exchange rate adjustment factor $e_{i, j, t}, v i z$.

$$
r_{i, j, t}=\alpha_{i}+\beta_{1, i} r_{m_{j}, t}+\beta_{2, i}\left[r_{U S, t}+e_{j, t}\right]+\varepsilon_{i, j, t}
$$

This procedure gives them a regression $R^{2}$ statistic for each stock $i$ in each country $j$, denoted $R_{i, j}^{2}$, that measures the percent of that stock return variation that is correlated with market return variation. They average the $R^{2}$ estimates of all firms in a given country, weighting them by the total variation of each stock's return to form a second synchronicity index, 


$$
R_{j}^{2}=\frac{\sum_{i \in j} R_{i, j}^{2} \mathrm{x} S S T_{i, j}}{\sum_{i \in j} S S T_{i, j}}
$$

This index measures the extent to which individual stock return variation is correlated with variation in market returns. It is sometimes more convenient to use $1-R_{j}^{2}$ as a measure of the extent to which individual stock return variation is due to firm-specific information. Since these measures have the statistically undesirable property that they are bounded within the unit interval, it is sometimes desirable to apply a logistic transform of $R_{j}^{2}$ into

$$
\mathrm{Y}_{j}=\log \left(\frac{R_{j}^{2}}{1-R_{j}^{2}}\right)
$$

which can be used conveniently as the dependent variable in regressions.

The behavior of the two indices reveals a clear negative correlation between economic development, as measured by per capita GDP, and equity return synchronicity. Figure 2a shows that synchronicity is minimal for advanced economies like the US and Canada. ${ }^{1}$ In contrast, the greatest synchronicity is evident in emerging economies like China, Poland, and Malaysia. The correlation between per capita GDP and the first and second synchronicity indices is -0.36 , and is statistically significant at a 0.001 confidence level.

It might be argued that a market with fewer stocks should exhibit a higher degree of synchronicity because each stock is a larger fraction of the market portfolio. This is clearly not driving our results. Developed countries like New Zealand, Ireland, and Denmark have fewer listed stocks than many developing countries, like China and Malaysia, yet they have much lower synchronicity measures. As a further check that the number of listings is not driving their

\footnotetext{
${ }^{1}$ These charts are taken from Morck, Yeung and Yu (2000).
} 
result, they use other synchronicity measures. For example, they directly count how many stocks move in the same direction in an average week to obtain

$$
f_{j}=\frac{1}{T} \sum_{\mathrm{t}} \frac{\max \left[\eta_{\mathrm{jt}}^{\mathrm{up}}, \eta_{\mathrm{jt}}^{\text {down }}\right]}{\eta_{\mathrm{jt}}^{\text {up }}+\eta_{\mathrm{jt}}^{\text {down }}}
$$

This index is again negatively and significantly correlated with per capita GDP ( $\rho=-$ 0.57 , $\mathrm{p}$-value $=0.001$, and generates a very similar ranking of countries in Figure $2 \mathrm{~b}$. Using the average correlation coefficient between the returns of randomly chosen pairs of stocks generates a very similar ranking, as do an assortment of other synchronicity measures.

Intriguingly, there are a few exceptions to this pattern. Japan, Spain, and Italy all have stock return synchronicity similar to that in low income economies. These are economies in which general property rights are well protected, but outside shareholders' property rights over their investments are not. We shall return to this point below.

\section{Structural Explanations}

The general correlation between return asynchronicity and economic development could be due to some systematic difference between the structures of developed and emerging economies. Any factor that causes the fundamental values of firms in lower income economies to move more synchronously than those of firms in higher income countries is a candidate. Less developed economies might have less stable macroeconomic policies, less diversified economies, more dependence on a few large firms, or more geographically concentrated economic activity that is more vulnerable to local "Acts of God". All of factors might cause firms in poorer countries have more synchronous fundamentals. 
Morck, Yeung, and Yu (2000) construct proxies for all these factors. Moreover, they directly estimate the synchronicity of firms' cash flows (constructed analogously to the returns synchronicity index $R_{j}^{2}$ ) to directly capture fundamentals synchronicity. Regressions of synchronicity, measured by $\mathrm{Y}_{j}$, on per capita GDP and all of these control variables plus the number of listed share (a control for market size) still show synchronicity to be highly significantly negatively correlated with per capita GDP.

These results withstand a battery of robustness checks, including: dropping outliers, substituting a logistic transformation of the alternative synchronicity measure

$$
\Psi_{j}=\log \left(\frac{f_{j}-.5}{1-f_{j}}\right)
$$

as the dependent variable, using data from other years (1993 and 1994), excluding countries with contemporaneous macroeconomic crises (first Mexico and then all of Latin America) from their sample, using alternative proxies for county wide and macroeconomic instability (variance in GDP growth, variance in inflation, etc.) and adding other variables such as a dummy capturing dependence on natural resources extraction.

All of these make a structural explanation along these lines unlikely. Another approach is called for to explain equity return synchronicity.

\section{Institutional Explanations}

Recall the Heinz example: Heinz's share price rises against a concurrent negative market return on the day when new positive information about the company's prospects emerges. The example illustrates how share value change upon the arrival of information that changes expectations, as modeled by Grossman (1976). Finance theory posits that risk arbitrageurs spend 
resources uncovering proprietary information about stocks and then earn an acceptable return by using that information to trade against less informed investors. Such trading by many risk arbitrageurs is thought to capitalize information into share prices (Grossman and Stiglitz (1980); Shleifer and Vishny, 1997). Roll (1988) suggests that firm-specific stock return variation is largely due to the trading activity of informed arbitrageurs moving prices, while market and industry-related variation is more likely to be the consequence of public announcements of information. It follows that stock returns should be asynchronous if informed arbitrageurs are active.

This raises the possibility that a dearth of informed risk arbitrageur might underlie the highly synchronous returns we observe in emerging markets. Informed risk arbitrage may simply be less economically attractive in these countries for a variety of institutional reasons.

First, in many low-income countries, political factors can have overriding influence on company fortunes, and such factors are hard to predict. Politicians can directly influence a company's earnings by open legislation, licensing requirements, repudiating commitments, and manipulating government projects, fees and taxes. The politically connected can confiscate corporate earnings with the help of their government friends. Horror stories of this sort abound. Outsiders would find it hard to reliably gauge future earnings, and insiders have better ways to make money than risk arbitrage. Moreover, even outsiders did predict a company's earnings, their property rights to those earnings are uncertain. A paucity of shareholder protection laws means higher earnings may disappear into the pockets of corporate insiders and never emerge as higher dividends for investors. For these reasons, firm-specific risk arbitrage is relatively unattractive in countries whose governments fail to honor private property rights properly, and informed trading correspondingly thin. 
If weak property rights discourage informed risk arbitrage, the proportion of uninformed players rises. Uninformed traders trade according to hard to fathom 'sentiment', or even government-primed trends, as may have been the case for the Chinese company Baiwen. The effects of a market dominated by noise traders are poorly understood. An influential model by De Long et al. $(1989,1990)$ argues that noise traders create market-wide sentiment risk unrelated to market-wide fundamentals variation. This added systematic risk drives informed traders out of stock markets, and thus promotes the survival of noise traders as a group. If insufficient property rights protection also drives informed traders out of the country's stock market, this should also promote the survival of noise traders. The elevated market-wide variation noise traders create would be apparent as high returns synchronicity unrelated to market-wide fundamentals variation.

Second, even if private property rights are protected from the state, shareholders' property rights as residual claimants to corporate cash flows may be ill-protected from powerful corporate insiders. This might again render informed risk arbitrage based on firm-specific information economically unattractive. La Porta et al. (1998) show that shareholder rights are indeed poorly protected in many countries that otherwise generally do protect private property. Morck, Stangeland and Yeung (1998) argue that wealthy families who control corporate groups can transfer resources between group member firms to their own advantage and to the detriment of public investors. This 'self-dealing' is akin to the 'income shifting' multinationals use to avoid taxes, but the objective is to keep money away from public investors rather than tax collectors. Johnson et al. (2000) refer to this practice as 'tunneling' and document several instances of income shifting within corporate groups that benefited the controlling families at the expense of public investors. 
Morck, Stangeland and Yeung (2000) argue that corporate insider may be less inclined to siphon off abnormal earnings due to economy-wide factors because such action is easier to detect unless the insiders controlling all other firms do likewise. In contrast, appropriating firmspecific abnormal profits requires no such concurrent action, and so is harder for public shareholders to detect. The consequence is that outside shareholders find arbitrage based on predicting firm-specific information harder to implement and less profitable where tunneling is more likely

Hence, in an environment when government protects private property rights in general, but fails to protect outside investors from abuse by corporate insiders, risk arbitrageurs may see little point in gathering and processing information to make firm-specific abnormal earnings predictions. Consequently, stock returns might primarily fluctuate in response to economy-wide factors, and synchronicity ensues.

To explore these arguments, Morck, Yeung, and Yu (2000) regress their synchronicity indices, $\mathrm{Y}_{i}$ (eq. 3) and $\Psi_{\mathrm{i}}$ (eq. 5) on per capita GDP, the structural economic explanatory factors, the number of listed stocks, and variables that measure property rights protection in general and shareholders' property rights.

To gauge general property rights protection, Morck, Yeung and Yu (2000) construct a "good government" index. This is the sum of three indexes measuring (i) government corruption, (ii) the risk of the government expropriating private property, and (iii) the risk of the government repudiating contracts - all taken from La Porta et al. (1998). The good government index can take values from zero to thirty, with low values indicating weak property rights. ${ }^{2}$

\footnotetext{
${ }^{2}$ La Porta et al. (1998) describe these three indexes as follows: The "corruption index" is an assessment of corruption in government by the International Country Risk Guide (ICR). Low scores of this index indicate that "high government officials are likely to demand special payments" and that "illegal payments are generally expected throughout lower levels of government" in the form of "bribes connected with import and export licenses, exchange
} 
To measure shareholders' rights against corporate insiders, they use a score card of legal rights compiled by La Porta et al. (1998). The measure can range from zero to six according to whether or not shareholders (i) can vote by mail, (ii) are barred from selling stock a few days prior to a shareholder meeting, (iii) can use cumulative voting for directors, (iv) have legal standing to sue directors or to force the company to buy back their shares, (v) have preemptive rights to new issues, and (vi) call extraordinary shareholder meetings relatively easily. Higher scores indicate more legal rights for shareholders. ${ }^{3}$

Morck, Yeung and Yu (2000) find that both "good government" and "shareholder rights" are negatively and significantly correlated with returns synchronicity (measured with $R_{i}^{2}$ [eq. 2], $\mathrm{Y}_{i}$ [eq. 3], $f_{i}$ [eq. 4], or $\Psi_{i}$ [eq. 5]). More importantly, when these variables are added to their regressions, per capita GDP becomes insignificant! Interestingly, while both the good government index and the proxy for shareholders' right reduce synchronicity, only the former is significant. Figure 3 illustrates the relationship between $R_{i}^{2}$ and the good government index. In this sense, our preliminary conclusion is that high synchronicity in stock returns in low-income countries and in emerging countries is attributable to a lack of government respect for private property rights.

controls, tax assessment, policy protection, or loans." The "risk of expropriation index" is the ICR's assessment of the risk of "outright confiscation" or "forced nationalization." The "repudiation of contracts by government index" is ICR's assessment of the risk of a "modification in a contract taking the form of a repudiation, postponement, or scaling down" due to "budget cutbacks, indigenization pressure, a change in government, or a change in government economic and social priorities." All three ICR indexes are averages of the monthly indexes for April and October from 1982 to 1995 . The good government index tends to be quite high for developed countries and quite low for emerging economies.

${ }^{3}$ La Porta et al. (1998) emphasize that, for such rights to provide effective protection, a country must have functional political and legal systems. It is therefore plausible that the anti-director rights index might be most relevant in countries with good government, where the rule of law prevails. La Porta et al. (1998) show that many countries, including some with strong property rights protection in general, poorly protect the property rights of public investors. This finding suggests that there might be enough variation in anti-director rights within our developed country subsample for statistical tests. 


\section{A Decomposition of Stock Returns Variation}

To better understand the economics underlying this institutional explanation, it is useful to revisit the synchronicity measure $R_{j}^{2}=\left(\sum_{i \in j} S S T_{i, j}\right)^{-1} \sum_{i \in j} R_{i, j}^{2} \cdot S S T_{i, j}$. We can write $R_{j}^{2}$ as $\left[\sum_{i \in j}\left(\sigma_{m, i, j}^{2}+\sigma_{\varepsilon, i, j}^{2}\right)\right]^{-1} \sum_{i \in j} \frac{\sigma_{m, i, j}^{2}}{\left(\sigma_{m, i, j}^{2}+\sigma_{\varepsilon, i, j}^{2}\right)}\left(\sigma_{m, i, j}^{2}+\sigma_{\varepsilon, i, j}^{2}\right)$, with $\sigma_{m, i, j}^{2}$ the variation in the returns of firm $i$ in country $j$ explained by market factors and $\sigma_{\varepsilon, i, j}^{2}$ the residual variation. Substituting the above into equation 3 yields

$$
\mathrm{Y}_{j}=\log \left(\frac{\sigma_{m, j}^{2}}{\sigma_{\varepsilon, j}^{2}}\right)=\log \left(\sigma_{m, j}^{2}\right)-\log \left(\sigma_{\varepsilon, j}^{2}\right)
$$

where the average variation in country $j$ stock returns explained by market factors is $\sigma_{m, j}^{2}=\frac{1}{n} \sum_{i \in j} \sigma_{m, i, j}^{2}$ and the average firm-specific variation in country $j$ stock returns is $\sigma_{\varepsilon, j}^{2}=\frac{1}{n} \sum_{i \in j} \sigma_{\varepsilon, i, j}^{2}$.

The decomposition in equation 6 indicates that stock return synchronicity can be due to either a high $\sigma_{m, j}^{2}$ or a low $\sigma_{\varepsilon, j}^{2}$ - or both. A high $\sigma_{m, j}^{2}$ can represent a high level of market volatility or a high level of noise trading in the sense of DeLong et al. (1990), whose model predicts that noise traders should create market-wide variation unrelated to fundamentals. A low $\sigma_{\varepsilon, j}^{2}$ can reflect a low rate of capitalization of the private information that Roll (1988) shows to be responsible for firm-specific return volatility. Morck Yeung and Yu (2000) show that high stock return synchronicity is associated with both high $\sigma_{m, j}^{2}$ and low $\sigma_{\varepsilon, j}^{2}$, as Figure 4 illustrates. 


\section{High Systematic Variation Unrelated to Fundamentals Accompanies Weak Property Rights}

Figure 5 illustrates further that systematic returns variation, $\sigma_{m, j}^{2}$, is substantially higher in countries with weaker general property rights, as measured by the good government index. In contrast, firm-specific variation, $\sigma_{\varepsilon, j}^{2}$, appears unrelated to general property rights protection.

The negative relationship between $\sigma_{m, j}^{2}$ and general property rights is not expunged by controlling for log per capita income, the structural variables, the number of listed securities, or systematic fundamentals variation. Since the controls include measures of systematic fundamentals volatility, we cannot reject the hypothesis that the high systematic returns variation in economies that protect private property poorly might arise from noise trading of the sort described by DeLong et al. $(1989,1990)$. In other words, the high stock return synchronicity in countries that poorly protect private property rights in general might reflect a lack of informed risk arbitrage and consequently (since arbitrageurs fail to drive out noise traders) a prevalence of noise trading.

\section{A Threshold Effect for General Protection of Property Rights}

Closer inspection of Figure 3 lets us partition countries by general property rights protection. That chart shows that the negative relationship between the Good Government index and synchronicity reflects a cluster of strong property rights countries with low returns synchronicity and a more diffuse cluster of weak property rights countries with high returns synchronicity. No statistically significant relationship is detectable within each cluster. Hence, Morck et al. (2000) describe a threshold effect. Once property rights are sufficiently strong, synchronicity is reduced - changes in the strength of property rights above or below that 
threshold, a good government index of about 25, are not associated with changes in synchronicity.

One interpretation of this is that property rights must pass a certain threshold to induce informed investors to enter the market in large numbers, and that in the absence of informed trading, noise traders dominate, inducing a high degree of synchronicity in share prices as DeLong et al. $(1989,1990)$ predict.

\section{Shareholder Rights Only Matter if Property Rights in General Are Secure}

This observation about the Good Government Index suggests a very important second look at the Shareholder Rights Index. Shareholder rights may be dead letters if the government fails to honor private property in general. Consequently, de facto shareholder rights may only exist in countries that grant such rights de jure and also honor private property in general. Consequently, shareholder rights should be positively correlated with firm-specific returns

variation, $\sigma_{\varepsilon, j}^{2}$, only in these countries. Figure 6 shows this to be so, and regressions controlling for structural factors, fundamentals variation, market size, and per capita GDP confirm the robust statistical significance of this relationship.

\section{Firm-specific Returns Variation and the Intensity of Informed Arbitrage}

The evidence garnered above is consistent with the view, first enunciated by French and Roll (1986) and Roll (1988), that higher level of firm-specific stock price variation are associated with more intensive informed risk arbitrage. This interpretation is consistent with other work.

Beny (2000) finds that a country's stock return synchronicity is less when insider trading is more restricted. The reason is that stronger insider trading restrictions allow more profitable 
informed risk arbitrage for outsiders. Fox et al. (2003) show that in the U.S. a stronger disclosure requirement raises firm-specific return volatility (that is, reduces the expression in (6) and raises the second term in the right hand side of (6)). In December 1980 the U.S. SEC changed its disclosure rule requiring every issuer's filings to contain a section with "management's discussion and analysis" of the issuer's financial results (the "MD\&A" rule). The change required managers to disclose any material information suggesting that the issuer's most recent results are not necessarily indicative of future results. Fox et al. (2003) identify the category of firms that are least likely to have good or bad news released; that is, the category of firms which are most likely to be a mixture of firms with no news or have bad news to hide. Their study shows upon the strengthened disclosure requirement, the mixed group experienced an increase in firm-specific stock return variation while the others did not.

Chang, Khanna, and Palepu (2000) report that better protection for property rights and a common law legal system raise the number of analysts per listed stock. One interpretation of this result is that stronger private property rights promote interest in informed trading, and thus induce more investment in information gathering and processing. Combining their data with the synchronicity indices $R_{i}^{2}$ and $f_{i}$ from Morck et al. (2000), we find synchronicity to be negatively and significantly correlated with the number of analysts per listed stock. The correlation of the number of analysts per stock with $R_{i}^{2}$ is -0.27 (p-value $=0.10$ ) and that with $f_{i}$ is -0.366 (pvalue $=0.26$ )

In the accounting literature, Collins, Kothari and Rayburn (1987), Collins and Kothari (1989) and others attempt to measure what they dub the 'information content of stock returns' by regressing current returns on future earnings changes. Durnev et al. (2003) show that, using US data from 1983 to 1995 , the returns of stocks exhibiting greater firm-specific returns variation 
relative to total variation are better predictors of future earning changes. Bushman et al. (2002) show that greater idiosyncratic variation is evident in countries with more developed financial analysis industries and a freer press.

\section{Summary}

In summary, stock returns are more synchronous in emerging economies than in developed economies. This is associated with measures of institutional development rather than economic development per se (such as per capita GDP). The key institutional development factors are the strength of private property rights in general and the legal protection accorded outside shareholders' vis a vis corporate insiders.

Our interpretation of these findings is that weak institutions deter informed risk arbitrage, which is primarily responsible for inducing firm-specific variation in rich country stocks. The high synchronicity in emerging market stock returns is due to a high level of market-wide variation that seems unrelated to market-wide fundamentals variation, we cannot reject a role for noise traders in those markets. Among countries that protect property rights in general, more legal rights accorded outside shareholders are associated with more firm-specific returns variation. This is consistent with the view that such shareholder property rights, in an economy that generally honors private property, encourage informed trading.

If our interpretation of these findings is correct, stock markets in emerging economies may be less useful as processors of economic information than stock markets in advanced economies. A companion inference is that asynchronous stock returns may be indicative of informed stock prices. Of course, we cannot at this stage definitively preclude other possible interpretation. 


\section{Synchronous Stock Returns, the Quality of Capital Allocation, and}

\section{Growth}

If higher firm-specific stock return variation is indeed associated with more activity by informed arbitrageurs and/or less activity by noise traders, more asynchronous stocks might induce a higher quality of investment by firms for several reasons. First, informed stock prices convey information about market participants' perceptions to managers, and better-informed managers should be able to make better capital budgeting decisions. Second, informed stock prices serve as a feedback mechanism. For example, negative price reactions will alert managers of shareholders' dissatisfaction with managerial decisions, including capital budgeting decisions. Third, more informed stock prices (i.e., transparency) mean better monitoring that restrains selfserving or inept managerial behavior, either of which can distort capital budgeting decisions. Higher quality capital investment decisions should, in turn, sustain a higher overall economic growth rate, all else equal. Likewise, more informed stock prices would lead to more reliable and thus more rigorous market for corporate control activities. The result is again more disciplined managerial behavior and thus better resources allocations.

In this section, we first survey some studies that point towards such a conclusion. We then turn our attention to the other important capital market, namely the banking market. We believe that the institutional environment that is associated with synchronous stock return would also hinder the performance of the banking market as a resources allocations device. In other words, the fundamental ingredient for efficient resources allocation is an economy's institutional integrity. We shall cite results that support the claim. Equity prices' informativeness per se, however, may still matter because of the mechanisms mentioned in the previous paragraph. We 
report some cross-country statistical evidence showing that economies with less synchronous stock returns do indeed grow faster.

\section{Stock Return Asynchronicity and the Quality of Capital Allocation}

Wurgler (2000) devises a direct measure of the quality of capital allocation. His starting point is that higher quality capital allocation implies more investment in industries that are growing rapidly and less investment in declining industries. His measure is thus an elasticity of capital expenditure with respect to value added,

$$
\ln \frac{I_{i, c, t}}{I_{i, c, t-1}}=\alpha_{c}+\eta_{c} \ln \frac{V_{i, c, t}}{V_{i, c, t-1}}+\varepsilon_{i, c, t}
$$

where $I$ is gross fixed capital formation, $V$ is value added (sales minus cost of intermediate goods), and $i, c$, and $t$ are subscripts for manufacturing industry, country, and time, respectively.

Using a data set spanning 28 manufacturing industries across 65 countries over 33 years, Wurgler (2000) finds a significant negative relationship between the quality of capital allocation and stock returns synchronicity, e.g., as defined in [4] (Figure 7). He also finds poor quality capital allocation to be associated with state ownership and poor minority investor rights institutional factors like those proposed by Morck et al. (2000) as responsible for stock return synchronicity. When all of these factors are included in the same regression, the synchronicity measure remains consistently statistically significant while the other two do not. These results are consistent with the view that informed arbitrage, as revealed by asynchronous stock returns, is a primary factor underlying high quality capital allocation.

Durnev et al. (2003) measure shareholders' perception of the quality of capital budgeting using marginal Tobin's $q$ ratios. Using U.S. industry data, they find that shareholders view the quality of capital allocation as closer to optimal in industries whose firms have less synchronous 
stock returns. They show that these results are not due to differences in fundamentals synchronicity and they also control for factors that may affect both the quality of corporate investment decisions and firm-specific stock variations like diversification, size, competition structure (Herfindahl index), liquidity, leverage, past investment in intangibles (e.g., R\&D and advertising spending). In addition, Durnev et al. (2000) show that in the U.S. industries with greater firm-specific stock return variations tend to utilize more external finance to support capital expenditure.

In summary, these results are consistent with the view that the quality of capital allocation is higher where stock returns are less synchronous. Again, other interpretations of these findings may well be possible, and further research is clearly needed.

\section{Banks as a Substitute for a Dysfunctional Stock Market?}

We have hitherto focused on the stock market as an information processing and capital allocation device. However, stock markets are thought to have only secondary roles in these regards to financial institutions, primarily banks, in many countries. Can a country's banking system substitute for a poorly functioning stock market?

There is a strong and respectable literature on the complementary and substitution nature of the bank (relations) and market based financing. Some also links the importance of the two types of financing at different stage of economics development (bank first and equity market later). Our argument here is that the overarching concern is institutional integrity - just like dysfunctional stock markets are associated with weak private property rights protection, weak property rights should also hinder banks from accomplishing efficient allocations of capital for several reasons. 
First, a government that does not respect private property rights in general might also fail to respect bank depositors' property rights, and apply political pressure on banks to divert capital to political insiders. The banking system might easily become a mechanism for collecting and distributing political rents at the expense of the population in general.

Second, weak private property rights might tempt bankers to use their banks' assets to advance their self-interest at the expense of their depositors. Banks in family corporate groups might, for example, divert capital towards uncreditworthy enterprises that are part of the same group. ${ }^{4}$ Or bankers might simply appropriate their depositors' wealth to benefit corporations in which they have vested interests. ${ }^{5}$ In short, it is hard to imagine a banking system functioning well in a country where property rights protection is lacking. It seems more likely that banks in such countries direct their depositors' savings towards uneconomical ventures controlled by political or family insiders.

La Porta et al. (2000) show that government ownership of banks is common around the world, and is especially common in countries with weak private property rights, heavy government intervention in the economy, and underdeveloped financial systems. They present empirical evidence supporting the view that state control of finance through banks politicizes resources allocation, both for the sake of votes and for bribes to office holders. Consequently, higher government ownership of banks appears to impede the development of a country's financial system, causing lower economic growth, and in particular lower productivity growth.

The variable they use is the extent of government ownership of the ten largest banks, based on 1995 data. Their most conservative measure, which we borrow, is the sum of the assets

\footnotetext{
${ }^{4}$ La Porta et al. (2001) convincingly show that is the case in Mexico.

${ }^{5}$ Morck and Nakamura (1999) argue that this occurred in Japan in the 1980s.
} 
of top ten banks in which the government voting stake is at least ninety percent as a fraction of the total assets of all top ten banks. ${ }^{6}$

Stock returns are significantly more synchronous in countries whose banking systems are more state controlled. The correlation coefficients of state bank control with our synchronicity measures $\Psi_{i}$ and $Y_{i}$ are 0.47 and 0.42 , respectively, with p-values 0.005 and 0.001 , respectively. State bank ownership is also highly negatively correlated with both the good government index $(\rho=-0.59, p$-value $=0.01 \%)$ and the shareholder rights index $(\rho=-0.34, p$-value $=4 \%)$. Our interpretation of the statistics is that a dysfunctional banking system tends to coincide with a dysfunctional stock market, and that both occur in countries that poorly protect both private property rights in general and shareholders' rights in particular.

Empirical evidence supports the current emphasis: institutional integrity matters the most. Levine (2002) examines how growth differs between bank-based and market based financial system. He finds that the bank versus market-based dichotomy is relatively unimportant compared to general measures of institutional integrity, such as the extent to which the legal code protects shareholders and creditors, and the general efficiency with which laws are enforced.

These results highlight the importance of the 'law and finance' view of institutions, articulated by La Porta et al. (1997, 1998, 1999, 2000), which holds that a sound institutional system is one that protects property rights and enforces contracts. They also buttress the financial service view, that sound institutions bridge imperfections in contracts, markets, and intermediaries to connect finance users and finance providers. That is, a sound institutional environment allocates capital efficiently.

\footnotetext{
${ }^{6}$ See La Porta et al. (2000), Table 2, last column.
} 


\section{Stock Return Asynchronicity and Economic Growth}

If returns asynchronicity leads to better investment decisions, it should be positively correlated with growth, particularly productivity growth. We therefore examine the relationship between economic growth and the synchronicity measure $Y_{j}=\log \left(\sigma_{m, j}^{2}\right)-\log \left(\sigma_{\varepsilon, j}^{2}\right)$.

\section{Data period, Dependent variables and the Synchronicity Measure}

Our sample is composed of fifty six countries spanning during years from 1990 through 2000. We use two measures of economic growth: growth in real per capita GDP, $\triangle G D P$, and growth in productivity, $\triangle P R O D$. All these data are year-by-year and we have 454 country-year observations.

Similar to King and Levine (1994) and Beck, Loayza, and Levine (2000), we define real per capita productivity growth as real per capita growth in GDP, $\triangle G D P$, less 0.3 times the growth rate in real per capita physical capital stock. Assuming that the capital stock was zero for every country in our sample in 1960 , we calculate physical capital stock recursively as $K_{i, t}=K_{i, t-1}$ $+I_{i, t}-\delta K_{i, t-1}$, where $K$ denotes capital stock, $I$ investment, and $\delta$ depreciation rate. We assume $\delta$ to be seven percent and use Penn World Tables 6.1 dataset to calculate $I^{7}$. The growth measures, $\triangle G D P$ and $\triangle P R O D$ are constructed annually from 1991 through 2000.

We obtain the stock price synchronicity measure, $Y$ as in equation 6 and as in Morck Yeung, Yu (2003). Our data are from 1990 to 1999; the sources are CRSP for the U.S. and Datastream for non-US countries. To avoid possible data errors in Datastream, we drop return observations greater than 100 percent or less than -90 percent. We use weekly stock returns to

\footnotetext{
${ }^{7}$ It is customary to begin the recursive formula from 1950, the first year the World Penn Tables 6.1 has data available. Since all the rest of data is from 2002 Worldbank World Development Indicators dataset, and its coverage starts from 1960, we choose 1960 as the beginning period.
} 
generate annual country level observations for $Y$. We exclude those country-year observations for which $Y$ is computed using fewer than eleven stocks. When we use $\triangle P R O D$ as a dependent variable, we further drop countries whose share of investment in GDP is missing for any of the years from 1960 through 2000 in the World Penn Tables 6.1.

$\underline{\text { Independent variables }}$

To estimate the relation between growth measures and stock prices synchronicity, we regress $\triangle G D P$ and then $\triangle P R O D$ on $Y$ and control parameters. We follow the usual practice to control for initial real per capita GDP, GDPI, and the market size, $L N$, which is the natural log of the number of stocks used to construct the stock price synchronicity measure. To control for macroeconomic instability we include inflation, INFL, the logarithm of one plus inflation rate, and government size, GOV, the logarithm of the share of government expenditure in GDP. We use the logarithm of exports plus imports as shares of GDP to capture the degree of openness of the economy, and call this variable OPEN.

We note that stock synchronicity, $Y$, could be an inverse proxy for capital market development. Morck, Yeung Yu (2000) show a strong negative correlation between the number of listed firms and stock synchronicity. A series of articles, e.g., King and Levine (1993, 1994), Levine and Zervos (1998), Levine $(1997,2002)$ link financial development to growth. It is therefore important to check whether our results survive the inclusion of additional control variables that reflect the level of financial development. This is essentially equivalent to adding our firm-specific returns variation measure to Levine's (2002) regressions.

Additionally, it may be the case that stock synchronicity per se can affect growth. Durnev et al. (2004) find that across U.S. industries corporate investment decisions are more 
firm value enhancing the more the returns are asynchronous. Durnev et al. (2000) show that in the U.S. industries with greater stock return asynchronicity utilize more external financing in supporting capital expenditure. Since all U.S. industries share the same institutional environment, these results suggest that returns asynchronicity may capture a unique effect associated with the firm-specific information content of stock prices and may have an independent effect on guiding resources allocation. Moreover, Durnev et al. (2003) find a relationship across U.S. industries between firm-specific returns variation and the ability of returns to predict future earnings. Would better informativeness in the stock market by itself have a positive relationship with growth?

We therefore include in our regressions controls for various dimensions of financial development. The variables are market capitalization, $M C A P$, log of the value of all listed shares over GDP and bank credit, CREDIT, log of the value of credit by deposit money banks and other financial institutions to the private sector over GDP, for stock market and banking development, respectively $^{8}$. As for institutional integrity, of which we focus on property rights protection, there is an array of plausible candidates. Given that we have a panel, we hope to have an institutional variable that has variations over the years. A suitable candidate is the quality of legal environment, $L A W$, proxied by the "rule of law" as reported in International Country Risk Guide. The Law variable is therefore a country-year variable. Other plausible candidate, like government corruption, tendency to expropriate and to repudiate contracts as used in La Porta (1998) do not have the same frequency of variations. The above variables are all a priori expected to be correlated with stock return synchronicity. The inclusion of these variables allows us to check when synchronicity per se has an independent effect on growth.

\footnotetext{
${ }^{8} \triangle G D P, G D P I, I N F L, G O V, O P E N, M C A P$, and CREDIT are constructed using 2002 Worldbank's World Development Indicators data set.
} 
Finally, we include $E D U C$, the logarithm of public expenditure on education over GDP to control the stock of human capital.

Table I provides details about the construction of these variables and about our data sources.

\section{$\underline{\text { Regression Model Specification }}$}

To control for countries' unobserved characteristics and world economic cyclical dynamics we estimate the relation between growth measures and stock price synchronicity using country-fixed, year-random effects model. The validity of the time-random effects is justified by the Breusch and Pagan (1980) test that rejects the null hypothesis that regression error terms are uncorrelated across countries. To reduce endogeneity all independent variables enter our regressions with one-year lag.

Note that multicollinearity is a concern. For example, the "Rule of Law" is highly correlated with the market capitalization variables and with the synchronicity. Although the synchronicity variable is only weakly correlated with "stock market capitalization/GDP" and "bank deposit/GDP," it is highly correlated with log GDP per capita, government expenditure share and inflation. To mitigate the collinearity problem, we enter our variables in blocks. First, we only include the synchronicity variable (Y), LN (the number of stocks used to estimate correlated Y) and the initial log GDP per capita. Then, we add Inflation, Trade Openness, and Government size (government expenditure/GDP). Finally, we add further Bank Credit/GDP, Stock Market Capitalization/GDP and the "Rule of Law." Finally, we add "education." We shall emphasize whether the synchronicity variable, Y, obtain a consistent regression coefficient. 


\section{$\underline{\text { Results }}$}

The estimation results when the dependent variables are $\triangle G D P$ (growth in per capita GDP) and $\triangle P R O D$ (productivity growth) are reported in Tables II and III, respectively. Specifications 2.1 and 3.1 control for GDPI and $L N$. Specifications 2.2 and 3.2 also control for $I N F L, G O V$, and $O P E N$. In all these specifications, synchronicity, $Y$, is negatively and significant; that is, lower synchronicity is associated with higher gross growth and productivity growth.

Regressions $2.3,2.4,3.3$, and 3.4 include the additional independent variables $-M C A P$ ( $\log$ of the value of all listed shares over GDP), CREDIT (log of the value of credit by deposit money banks and other financial institutions to the private sector over GDP), Law (Rule of Law index), and Educ (education). These regressions reveal whether synchronicity per se influences growth. The difference between them is that the $E D U C$ variable is added to 2.4 and 3.4. Returns synchronicity consistently attracts a negative and highly significant coefficient in regressions explaining both real per capita GDP growth and total factor productivity growth. Interestingly, the inclusion of education reduces the significance of synchronicity, but still leaves the variable significant at the $10 \%$ level. We have interpreted synchronicity as an indicator of the intensity informed risk arbitrage activities, and the prevalent of informed risk arbitrage is related with a country's education level. Hence, the observation is not surprising. ${ }^{9}$

According to Tables II and III, price synchronicity is negatively and significantly correlated with both real per capita GDP growth, $\triangle G D P$, and productivity growth, $\triangle P R O D$, across all regression specifications. These results are consistent with our hypothesis that

\footnotetext{
${ }^{9} E D U C$ is available only for roughly 53 percent of our original sample.
} 
asynchronous returns signify informed stock pricing, and that this raises the quality of capital allocation decisions and hence spurs economic growth.

\section{$\underline{\text { Robustness }}$}

We have checked that our results are not due to outliners. Still, one may be concerned that the inclusion of East Asian countries may affect our results. Many Asian countries experienced deep financial crises in the data period (e.g., in 1997 and 1998). These countries' stock returns are also known to exhibit high stock return synchronicity, as Figure 2 shows. While arguably these observations are what we suspect should be the case, we re-ran our regressions without the East Asian countries. Our results remain unchanged ${ }^{10}$.

Another concern is that Russia may be an outlier because of the crisis at the end of the nineties. We repeated our regressions without Russia. Our results remain unchanged. Indeed, Figures 8 and 9, which plot the relationship between our synchronicity measure and real GDP and productivity growth, indicate that our results are unlikely to be caused by just a few very low growth countries.

Another concern is whether our results apply to economies in transition, which is this paper's focus. We did not have enough data to re-run our results using only well known transition economies like the Eastern European countries. However, we can re-run our regressions by partitioning our sample into high and low income economies. It turns out that our results are not changed in either group. Indeed, the significance level of stock return synchonricity is slightly better in the low income country sample.

\footnotetext{
${ }^{10}$ Specifically, the stock price synchronicity measure, $Y$, remains significant at least at ten percent level across all specification in Tables II and III, except for specification 3.4. In that case the significance is eleven percent due to, perhaps, a smaller sample size.
} 
Finally, there may be a concern that the linkage between the lagged measure of stock return synchronicity and growth is due to reverse causality. High growth may stem from a high level of creative destruction; namely the demise of many existing firms and the growth of many upstarts. This line of thinking builds on asynchronous firm level fundamental (e.g., asynchronous firm level earnings per dollar assets) - high future growth is related to asynchronous future firm level fundamentals which are in turn reflected in current asynchronous

stock returns. However, such case is unlikely to be the sole reason for our result. Morck, Yeung, and $\mathrm{Yu}$ (2000) already show that the relationship between economic development and stock return synchronicity exists even after controlling for synchronicity in firm level fundamentals.

\section{Transition to What?}

The results surveyed above suggest the following:

i. An institutional environment that protects private property rights is an important precursor to economic growth. In part, this is because property rights protection in general, and shareholder rights in particular, promote informed arbitrage in stocks, and thus lead to more efficient stock markets. All else equal, more asynchronous stock returns are associated with more private information being impounded into stock prices by informed arbitrageurs, and thus with more efficient stock markets.

ii. Asynchronous stock prices are important signals for efficient capital allocation. That is, a more efficient stock market lets the economy allocate capital more efficiently. More asynchronous stock returns are indeed associated with higher quality capital investment decisions, measured either as the response of investment to growth in value-added or as 
shareholders' assessment of corporate capital budgeting decisions. Not surprisingly then, asynchronous stock returns are associated with faster economic growth and faster productivity growth, even after controlling for the size of the equity and direct credit markets and the integrity of the legal environment.

iii. Banks are not adequate substitutes for efficient equity markets in these functions in economies where property rights protection is generally poor.

These extrapolations are consistent with the arguments of Hayek (1945) that an economy requires a continual re-allocation of resources in response to continually changing demand conditions, technology, and resources availability. Hayek (1945) argues that, in any reasonably large and complex economy, a central planner can neither collect the information necessary to make optimal decisions nor enforce the central plan without requisitioning such vast resources as to bankrupt the economy. Moreover, the sweeping powers planners possess are likely to induce them to skew economic decisions to advance their private interests, rather than social welfare. The general defalcation of central planning in actual economies suggests that the problems Hayek outlined are more difficult to restrain and thus are more serious impediments to economic growth.

Hayek (1945) argues that a market economy can accomplish what central planning cannot. Market prices serve an information processing function and decentralized profit maximization subject to those prices allocates resources efficiently. The essence of this system is that, when individuals have economic freedom and secure private property rights, profit incentives lead them to collect information and allocate resources efficiently. These actions themselves generate the price system that channels resource allocation. 
Capital markets and the prices of capital assets have an especially important role in a system of decentralized planning. Asset prices are indicators of investment value and the capital markets are information processors. Within the system, company mangers are entrusted with obtaining and allocating an economy's capital. In economies where general property rights are better honored, and outsiders' property rights more securely protected, two things happen. First, asset prices are truer indicators of investment value because of the profits large numbers of arbitrageurs make as their trading pushes asset values towards those values. Second, managers are more trustworthy agents for investors because more efficient asset prices render corporations more transparent to investors, and thereby expose insider theft or incompetence. In addition, untrustworthy managers will be disciplined - from being shunned by investors and face higher costs of capital to being replaced. The asynchronous stock returns in developed economy stock markets are an affirmation of such decentralized resource allocation in action. The synchronous returns in emerging markets are evidence of a lack of discrimination between different firms in capital allocation. The essence of the results in the previous section is that poor property rights can lead to dysfunctional capital markets and thus poor resources allocation.

A non-planned economy does not necessarily function like a Hayekian capital economy. An economy in which most firms are tightly controlled by a small number of extraordinarily wealthy, politically powerful families is, in many ways, similar to a centrally planned economy controlled by a small number of bureaucrats. In both, hierarchical decision-making replaces market mechanisms. An economy in which a small number of individuals or families makes all major capital allocation decisions, like a centrally planned economy, is at a disadvantage. It is apt to suffer from problems associated with the costs oligarchs must incur to gather and process 
information, the costs they must incur to enforce central decisions, and the welfare losses associated with self-interested behavior by its oligarchs.

Transition economies are abandoning communist command economy policies. The stated goal of economic transition is the replacement of those command economies with market economies. However, our concern is that many transition economies may merely be substituting one sort of command economy for another. That is, communist economic dictatorships being displaced by a handful of oligarchs - extremely wealthy, politically well-connected families and individuals.

The government is supposedly in charge of the transition process. Given the superior performance of economies with general property rights and property rights assignment and protection to corporate outsides, transition economies should move to protect private property rights. ${ }^{11}$ Clearly, many are not doing this. Understanding why and how governments act in managing the transition process is therefore an important problem in the economics of transition.

Governments are composed of human beings, political insiders, who act to maximize their own utility subject to constraints reflecting the interests of their political constituencies. Better protection of outsiders' property rights limits the economic power and freedom of insiders. Moreover, strengthening outsiders' property rights affects the distribution of income, wealth, and power in an economy. It is likely that the political insiders would view such a redistribution of private property rights as contrary to their interests. How to institute the

\footnotetext{
${ }^{11}$ For example, the Mexican Congress approved in 1999 a comprehensive set of financial reforms which will have the effect of increasing the diversity of investors in the Mexican market:

- $25 \%$ or more of the company's Board of Directors must be independent

- An audit committee of the board must examine all related party transactions

- Minority shareholders representing $10 \%$ of the votes may appoint a director

- Minority shareholders representing $20 \%$ of the votes may reject resolutions taken at shareholder meetings. Mexican firms have responded to this by either delisting or by adopting more transparent relations with investors. The change has been noticed, foreign investors comment that it is easier to invest in Mexican firms than for example in Chilean firms. That means it is easier to get access to management for information.
} 
property rights necessary for a stock market to function properly is a non-trivial political economy question.

Research on this question is, however, sparse, but the picture is not sanguine. It is our belief that the literature has not yet reached a point of maturity for us to offer a summary of competing systematic thoughts and their empirical validation. We therefore take a different approach. In the following sections, we shall describe a not unusual situation where rich elite control a large amount of corporate assets, their rent-seeking success keeps politicians their capture or that the politicians and their interests merge. The end result is an "economic entrenchment" equilibrium in which the elites and politicians are in a collusion that benefits both but at the expense of the rest of the economy. A critical component of economic entrenchment is that the government, being the capture of the elites, does not establish good property rights to protect outside investors. More generally, it does not implement policies that create an environment inductive to entrepreneurial upstarts. We then attempt to outline the basic components that lead to economic entrenchment. Also, we shall describe studies that contribute to the thought. Finally, we shall point out that economic entrenchment is almost natural in some transition economies.

\section{Economic Entrenchment is Common}

A close inspection of corporate ownership across countries suggests that "economic entrenchment" of a few very wealthy families is the rule, rather than the exception. By economic entrenchment, we are referring to the situation that a few very rich families control a large number of corporations through a pyramidal structure. Their rent-seeking behavior hinders capital market development and generally the development of property rights protecting 
institutions. At a result, while the entrenched elite preserve their economic power and interests, the country's economic growth is compromised.

A precondition of economic entrenchment is concentrated control of corporate assets within an economy. La Porta et al. (1999) report that large corporate groups controlled by a few wealthy families are the preponderant means of corporate control throughout the world. Widely held public firms are predominant only in the US and UK. In these economies, corporate ownership is diffused and the chief corporate governance concern is "other people's money" agency problems - managers using shareholders' money to pursue their self-interest. Jensen and Meckling (1976) argue that this sort of problem is mitigated if insiders own more stocks. However, Morck, Shleifer and Vishny (1988), Stulz (1988), and others argue that large insider equity stakes can induce another type of agency problem - managerial entrenchment - because managers who own equity blocks cannot readily be displaced even if they are inept. Morck, Shleifer and Vishny (1988) argue that entrenchment becomes economically important in US firms where managers' stake exceeds five percent, though other studies argue for a higher threshold. Shleifer and Vishny (1986) argue that large outside shareholders, such as pension funds, are a better check on self-interested managerial behavior because they do not induce managerial entrenchment.

Outside the US and UK, most large corporations are members of corporate groups. In general, a few very wealthy families in each country control these groups. (The main exceptions are Japan and Germany, where a few very large banks exercise substantial corporate control over corporate groups.) La Porta et al. (1999) report that corporate groups virtually always have a pyramidal structure. Pyramid groups are hierarchical structures where an insider, usually a wealthy family, owns a control block in the top company, which owns control blocks in other 
companies, each of which then controls yet more companies, and so on - with public shareholders owning the remaining stock at each level. At the same time, in the pyramidal structural the controlling owner retains control of each key corporation by placing family members, or directly "related" parties, in top management positions. Figure 10 illustrates this structure.

It is important to emphasize that pyramids are not instances of concentrated ownership of the sort recommended by Shleifer and Vishny (1986) as solutions to the agency problems described by Jensen and Meckling (1976) as afflicting widely held firms. In fact, corporate pyramids are rife with such agency problems, and with other agency problems that generally do not afflict widely held firms. Morck, Stangeland, and Yeung (2000) describe control pyramids and the corporate governance problems they incubate.

First, firms in the lower levels of the pyramid are subject to extreme agency problems of the sort modeled by Jensen and Meckling (1976). This is because these firms can be almost entirely owned by public shareholders. For example, in Figure 10 the family owns $51 \%$ of Firm A, through it $25.5 \%\left(=0.51^{2}\right)$ of Firm B and other companies in the pyramid's second layer, through these $12.25 \%\left(=0.51^{3}\right)$ of Firm C and other companies in the third layer, and so on. The family's actual ownership stake in companies in Firm F (in the sixth level of the pyramid) is $0.51^{6}(=1.76 \%)$, yet the family fully controls this firm because it fully controls each firm above it in the pyramid. If some of the firms in the pyramid are controlled with multiple voting stock, the separation of ownership from control is even greater. The Bronfman corporate group in Canada extends sixteen levels deep, and European, Asian and Latin American pyramids are equally large. 
Second, the family is entrenched - it controls a majority of votes in each company in the pyramid, and so cannot be displaced, even if the family patriarch is inept. In contrast, inept managers in a widely held firm can be removed - by the board, by proxy contests, and by takeovers.

Third, pyramids foster a third sort of agency problem. Morck, Stangeland and Yeung (2000) describe how the controlling family can use inter-corporate transactions (including financial ones) at artificial transfer prices to shift income away from firms low in pyramids towards firms near the apex. This is because the controlling family actually receives a large proportion of the dividends firms near the apex pay, but most of the dividends from firms near the base of the pyramid accrue to public investors - either directly or via the firms above it. Johnson et al. (2000) refer to such income shifting as tunneling, and describe several cases of such behavior.

Thus, economies whose firms are organized into pyramidal family controlled corporate groups are afflicted with widespread "other people's money" agency problems, including wasteful investment, widespread managerial entrenchment agency problems, and an additional type of agency problem, self-dealing or tunneling, that is not present in the US and UK. Firms in most economies in the world are subject to a "triple whammy" of agency problems. This is likely to negatively affect an economy's performance. In addition, because of the personal benefits, a more able individual may not be able to purchase control from the controlling owner even if she can generate more cashflow from the pyramid of corporations (see, e.g., Bebchuk, Kraakman, and Triantis (2000)).

If heirs are superior managers, that may not be a dreadful problem. Unfortunately, heirs are likely to be less talented than entrepreneurs on average, and so are more likely to be the 
source of entrenchment agency problems. While founding corporate parents could be superior entrepreneurs, heirs are unlikely to escape "regression" towards the mean in talents.

Finally, the elites, through their pyramidal structure, have amassed significant control of an economy's corporations. They have market power in both the goods and the capital market (Morck, Stangeland, and Yeung (2000)). Even if capital is used efficiently within the pyramid controlled by the dominant owner, it is possible that capital is over used within the pyramid while outsiders are deprived of capital (Almeida and Wolfenzon (2003)).

The puzzling question is why a situation that substantially compromise economic growth be allowed to emerge and persist. Why would policies and regulations not be applied and enforced to protect investor rights and thus improves corporate governance and encourages healthy capital market developments? Given the above description, corporate governance is poor, investors have little property rights and will be apathetic. Investor apathy reduces informed risk arbitrage and information content in capital market, thus poor resources allocations as the empirical results in Section IV indicate.

Our response is that the elites conduct an entrenchment exercise via their collaboration with the political system. First, established insiders may view private property rights for outsiders as an undesirable limitation on their own freedom of action. By undertaking political rent-seeking to weaken outsiders' private property rights, insiders can deeply entrench themselves. The insiders' manipulation of corporate resources, mis-investment, and other mismanagement can remain unchallenged.

Second, established insiders may undertake political rent-seeking to preserve the status $q u o$, in which they have a vested interest. Since capital markets are primary mechanisms for distributing capital to promising upstart firms that can threaten this status quo, undermining this 
function of capital markets might be a key objective of their political rent seeking and might further deepen their entrenchment. Undermining the function of capital market weakens the rising of competition and reduces disciplinary pressures from the market for corporate controls.

Third, openness to the global economy, and to global capital markets in particular, can erode the positions of these entrenched elites. This is because trade openness limits local politicians power to protect old firms; while capital openness lets local entrepreneurs attract foreign financial backing (and lets local savers invest in firms other than those controlled by the entrenched elite, cutting off their monopsony power in capital markets as well). Also, capital openness, especially in the form of direct investment flows, allows "outside parties" to compete for investment opportunities (and reduces the entrenched elites' monopsony power in acquiring investment projects). This reasoning suggests that capital market liberalization may be a critical issue in emerging and developing economies. It also suggests that local entrenched elites should lobby hard against globalization, and particularly hard against capital flow liberalization.

Rent-seeking by the entrenched elites is a plausible explanation of the negative correlation between economic growth and inherited billionaire wealth. Morck, Wolfenzon, and Yeung (2003) suggest that "economic entrenchment" is a sub-optimal "political economy" equilibrium among three parties: the elite, the common people that comprise of the rest of the economy and the politicians. The three part theme - rent-seeking to limit policies protecting outsiders' property rights, to undermine capital markets that might finance outsiders to the elites' circle, and to isolate the economy from foreign capital and competition - when successfully implemented by the elites represents an equilibrium that benefits the elites at the expense of the rest of the economy. This equilibrium is possible because the elites are able to pay the politicians enough so that they would engender a property rights system that favors the elites. At 
the same time, the "hurt" common party is not able to generate enough payments to politicians to bribe them to change the property rights system. We shall expand on their arguments in the next section when we discuss the likelihood of entrenchment in transition economies.

The economic entrenchment equilibrium has been proposed by many. Veblen (1899, 1904, 1923) point to the capture of economic institutions by vested interests. Olson (1982), examining the evolution of institutions, attributes the fall of nations to rent-seeking. Morck (1995) proposes that old, established families are more discrete and reliable partners for politicians and bureaucrats in the favor trading that underlies most political rent-seeking, and so have a comparative advantage in rent-seeking.

Morck et al. (2000) report that economies whose wealth is highly concentrated in the hands of a few old families grow slower than other comparable economies. They present evidence consistent with the view that old, wealthy families have privileged access to capital, and that their political rent-seeking erects barriers against inward foreign investment so as to protect their vested interests. They also note that the US-Canada Free Trade Agreement (FTA), which included provisions opening Canada more fully to foreign investment, disproportionately harmed firms controlled by old families and benefited independent firms. They further show that firms controlled by old families appear to have enjoyed preferential access to capital prior to the FTA, but not subsequent to it.

Rajan and Zingales (2003) show that the entrenched equilibrium can be quite common. At the beginning of the twentieth century, many economies had huge, highly developed stock markets. For example, Argentina and France, by some measures, had stock markets as large as that of the US. They go on to document a "great reversal" whereby many stock markets were downsized and pared away by regulators. They suggest that these reversals were due to rent- 
seeking by established insiders, and also show that economic openness could prevent reversals. As a result of rent-seeking, these economies experience for much part of the twentieth century an equilibrium of low performing capital markets.

\section{Economic Entrenchment and Transition}

To understand the relationship between economic entrenchment and transition economics, one needs to pay explicit attention to the dynamics and the components that affect the formation of an equilibrium. ${ }^{12}$ The pertinent question is how economic entrenchment may take place - what are the initial conditions that facilitate the development? Thorough answer to the question is likely beyond the scope of the current undertaking. We focus on the part that is related to economics in transition. The economic history literature provides some guidance.

Economic historians Sokoloff and Engerman (2000) and Engerman and Sokoloff (1997) suggest that the initial endowment that supports the initial economic growth affects the initial distribution of economic power which subsequently shapes the institutional development that determines long run growth. When the initial economic activities that trigger growth lead to even distribution of economic power, the subsequent development of institutions is more growth inducing. On the other hand, when the initial activities lead to more concentrated distribution of economic power, the elites can and will use their skew share of resources to obtain privileged access to political power; they then use the coercive power of the state to extract rent and to keep the majority at bay in sharing power and resources.

The authors argue that in the New World locations like Barbados, Cuba, and Jamaica with large labor intensive plantations, plantations owners had the resources and incentive to

\footnotetext{
${ }^{12}$ The arguments in this section draw on Morck, Wolfenzon, Yeung (2003).
} 
institute biased policies that forbid the entry of competition and empowerment of the working class and outsider. In the "Spanish America," the initial revenue sources were mines and abundant native labor. The Spanish colonial master built on pre-colony social organization that had a distinct hierarchy which deprived laborer of economic resources and power. In both type of location, the initial wealth distribution was skew, the elites (plantation and mine owners) were rich enough to finance future capture of investment opportunities, and rights to their subordinates (laborers) would be against their existing and future economic and political interests.

On the contrary, the New World composed of the United States and Canada did not have large scale plantations and their development was based on laborers of European descent who had relatively high and similar levels of human capital. The settlers had more homogenous wealth distribution, each working on a small plot of land because of the limited advantages to large producers in the production of grains and hays predominant in the region. The evenness in the initial distribution led to institutions that provide more equal treatments and opportunities to members of the populations. Also, they spent more on education for the population as a whole.

Acemoglu, Johnson, and Robinson (2001) emphasize the initial incentive of the settlers. The authors examine the economic growth of British colonies. They argue that in the colonies where European settlers could survive would demand development of institutions that enforced the rule of law and encourage investment. (Note that settlers were not wealthy incumbents.) In places where Europeans could not survive and settle, exploitative "states" were developed instead. Using the settlers' mortality rate as an instrument, they find that that "settlers' mortality rate affected settlements; settlements affected early institutions; and early institutions persisted and formed the basis of current institutions. Where the mortality rate was high, settlers developed "extracting" institutions. Where the mortality rate was low, they developed 
institutions that enforced the rule of law and encourage investment. The implication of the initial institution development depends on the desire of the early settlers - exploitative or development for the long haul.

Morck, Wolfenzon, and Yeung (2003) point out that the above works suggest several important focal points in considering institutional development: (i) initial distribution of resources, (ii) the preference of the "players," (elite, common people, and the government), and (iii) institution development shows long term persistence.

To proceed further to answer the question what leads to economic entrenchment, it would be useful to set up a conceptual framework. Again, we draw on Morck, Wolfenzon and Yeung (2003) in the following.

Consider that a society is composed of three interest groups: one group is composed of current entrepreneurs who own existing business operation, another group represents workers who own no business operation but can be future entrepreneurs, and the government. The two groups care for their own economic interests. The government cares for economic development but also value side payments from any group.

The presumption is that the government has the authorities and capability to choose and implement institutional development - good or bad property rights protection. Good property rights protection can lead to more financing of investments and thus better growth which the government values. However, with enough side payments, which the government also values, the government may be enticed to choose to develop poor institutions which may be (but not necessarily) in line with the first group's interest. Likewise, the second group may be able to 
generate enough side payments to entice the government away from choosing poor property protection institutions. ${ }^{13}$

Economic entrenchment is the case where the first group wants to and is capable of making enough side payments to co-opt the government to hijack institutional development to its favor - resulting in poor property rights protection for the second group and depriving them of opportunities to grow economically as entrepreneurs and investors.

The question is what initial conditions are conducive to economic entrenchment. The economic historians' studies reviewed above provide useful clues for conjectural extrapolation.

The first is the initial condition - how it affects the initial wealth distribution and the desire of the current business owners. The presumption is that the more even the wealth distribution the less likely is any group of business owners to have enough resources to bribe the government to run poor property rights protection. There is another reason for more even wealth distribution to lead to better policies and institution development. The effect of even wealth distribution is that it is unlikely for any interest group having dominant ability to bribe the government to make its favored policy choice. Under this circumstance, the government will by itself push for policy improvement because it is assumed to value economic performance and policy improvement raises economic performance.

The more skewed wealth distribution is towards the elites (i.e., the initial business owners who have gathered wealth), the more likely that they are able to make enough side payments to "convince" the government to run their favored policy. At this point, the business owners'

\footnotetext{
${ }^{13}$ There could be multiple equilibria. Let us conceptualize that property rights protection has a high and a low level. "Multiple equilibria" is the following: After a high level of protection is installed, the elites are not able to gather enough resources to bribe the government enough to entice it to switch policies and regulations, including enforcement, to the low protection level and yet still be better off. And, after a low level of protection is installed, common people are not able to collect enough resources to bribe the government to switch to high protection and still be better off. A reason for the presence of multiple equilibria is that an equilibrium affects the resources that the elites and the common people have and that the capital market for raising funds for political rent-seeking is conceivable imperfect - forward cashing in of expected future benefits may not be a time consistent transaction.
} 
preference matters. While it is obvious that the common people's preference is to have good property rights, the business owners' preference is less certain. When the business owners have inadequate internal funds to capture future investment opportunities, they are more likely to prefer good institutional development. However, when they do, they are more likely to prefer low property rights protection. The reason is that high protection actually allows more trusting capital market operations and thus lower cost of capital. At the same time, it generates more competition for future investment opportunities. The current business owners' preference is based on the balance between the forces. Notice that current business owners' preference is not necessarily uniform. The richer among them are more likely to favor low property rights protection for unrelated parties while the poorer favor the opposite.

Putting the above together, we can deduce that the more even the wealth distribution in a transition economy, the less likely economic entrenchment takes place. Also, the more abandon future investment opportunities and the more even wealth distribution, the less likely economic entrenchment takes place.

The second conjecture is that transactions costs matter, as pointed out in Morck and Yeung (2003) and discussed in boarder terms in Olson (1982). Side payments to the government have to be collected from members of a group. That involves transaction costs, by which we refer to the resources needed to overcome free rider problems and the resources involved in organizing and collecting side payments donation. The transaction costs are lower the smaller the number of members in a homogenous interest group. The transaction costs are therefore lower the lower the number of super rich current business owners.

There is, therefore, a presumption that the business owner group has a transaction costs advantage - the number of "member" in the business owner group is much lower than the 
number of "members" in the common people group. The consideration again points to that wealth distribution matters. The more skewed wealth distribution is, the more likely the number of members in group one is small and thus the transactions costs in organizing them for rentseeking.

The third consideration is the government's relative interest in side payments and economics growth. The more weight the government gives to the side payments, the more likely it can be "bribed" to implement low property rights protection policies. The condition for that is likely poor social transparency - low level of free press and low level of education. Free press exposes inappropriate corporate self-dealings as well as poor government policies. Dyck and Zingales (2002) show that independent free press mitigates corporate stealing. High level of education raises the number of potential entrepreneurs and thus the contribution of good property rights policies on economic growth. (Good property rights policies raise the amount of financing available. The impact of more financing is greater the larger the number of potential entrepreneurs.)

\section{Economic Entrenchment is Natural in Transition Economies}

All of this suggests that many transition economies might become hothouses for economic entrenchment. All transition economies have legacies of central planning and extensive bureaucratic involvement in the economy that ingrained traditions of using "connections' to control quotas, capital allocation, access to hard currency, and the like. In many transition economies, some entrepreneurs get rich fast, perhaps because of prior positions and connections. The initial skew wealth distribution and connection between the rich and politician facilitates the rich's rent-seeking to retain economic power. At the same time, their preference 
for closing out others in wealth creation is enticing. Insiders with "connections" have preferential access to bank capital, securities issues, and state subsidies. In contrast, outsiders lacking "connections" and wealth face severe capital constraints. Finally, in many of these economies, social monitoring like free press is not an established tradition. As well, the number of able potential entrepreneurs is limited.

Property rights protection for outsiders, particularly outside shareholders, is a restriction on the freedom of action these tycoons enjoy, and is consequently a hindrance against which they will lobby strenuously. Since banks and stock markets are needed to provide capital to the tycoons, they cannot be destroyed utterly, but must be controlled - either directly or through political lobbying. Capital flows to the tycoons' group firms at monopsony prices and not to upstart firms unless the return exceeds a monopoly price plus the damage the additional competition will do to the tycoon's existing businesses. Moreover, the absence of strong private property rights protection in general, and shareholder rights in particular, in many economies makes risk arbitrage in their stock markets both difficult and unrewarding. Thus, the stock market, the banking system, and the government can all be counted on to allocate capital inefficiently but in favor of the current tycoons. And since globalization, and free capital flow in particular, not only make capital available to upstarts, but also undermine politicians' powers to respond to lobbying, this also must be fought. Indeed, many transition economies are fighting hard against openness, especially capital market openness.

When the first generation of tycoons grows senile or passes control to their heirs, lower quality management occurs and the economy has a pervasive entrenchment problem. Since old moneyed families may have a comparative advantage at rent-seeking, all of the above problems grow worse and the economy's entrenchment problem deepens. 
How economic entrenchment can be overcome is also poorly understood. The situation just described can be understood as a self-reinforcing low-level equilibrium. Rajan and Zingales (2003) argue that entrepreneurs grew wealthy in the early stages of industrialization in many countries, but that the descendants of these entrepreneurs were less able to use rent-seeking to lock in their economic control in countries with legal systems derived from British Common than in countries with French Civil Law systems. That is, Common Law makes rent-seeking and entrenchment less stable by better empowering outsiders, and protecting private property rights. Political revolutions such as the Glorious Revolution in England and the War of Independence in the United States led to financial reforms that toppled existing entrenched elites. The scandals of the Roaring Twenties led to legal reforms in the US and other countries that enhanced shareholders' legal rights against corporate insiders.

However, the widespread prevalence of family-controlled corporate groups, entrenched old money, and low economic growth suggest that escaping this low-level equilibrium is difficult. Only a handful of countries in Western Europe, North America, and the Pacific Rim have done so to any economically important extent. Elsewhere, even in the predominantly Western countries of Latin America, economic entrenchment seems discouragingly permanent.

Openness can change these dynamics. As we mentioned above, Morck et al. (2000) show that the Canada-US Free Trade Agreement seems to have systematically tilted the economic playing field in that country against firms connected to old money and towards independent firms. This was accompanied by an apparent end to old money firms' preferential access to capital. They go on to show that old money firms became much less important to the Canadian economy in the years immediately after free trade, due both to retiring Canadian entrepreneurs selling out rather than bequeathing their firms to their children, and to heirs selling 
out. Rajan and Zingales (2003) show that financial market development is greater the more open and industrialized the economy. Their argument suggests that global openness creates pressures on closed economies to open up. An important side benefit of global openness is that it breaks up economic entrenchment.

Openness, particularly openness to global capital flows and foreign direct investment, probably has the aforementioned apparently salutary effects for several reasons (see, e.g., Morck et al. (2004). First, openness engenders competitive financing, so that local upstarts can obtain financing from abroad on competitive terms. Innovative Israeli firms have obtained financing on the American NASDAQ stock market, sidestepping both Israeli banks and the Israeli stock market. Second, foreign firms can enter domestic markets, through foreign direct investment, exporting, or joint ventures with domestic firms. This renders starving local competitors of capital an ineffective strategy for preventing product market competition. Third, economic openness limits the power of politicians to intervene in the economy, and hence limits the usefulness of political rent-seeking in general. Openness is a country's pre-commitment to limit political economy rent-seeking. Fourth, given these considerations, established insiders may see selling out as their best strategy, and may come to view a more developed capital market as a way to fetch a higher price when they sell their firms. Thus, economic openness, and the free flow of capital in particular, hold promise as ways of weakening the grip of established elites, fomenting financial development, improving the quality of capital allocation, and promoting economic growth. Indeed, Morch et al. (2004) report that capital market openness reduces stock return synchronicity in emerging economies.

\section{Conclusion}


An institutional environment that protects private property rights appears to be an important precursor to economic growth. In part, this seems to be because property rights protection in general, and shareholder rights in particular, promote informed risk arbitrage in stocks. This, in turn, leads to asynchronous stock prices, which serve as important signals for efficient capital allocation. A higher quality of capital allocation ultimately leads to higher productivity and faster economic growth.

This has direct implications for transition economies. Many transition economies have established stock market, hoping these can stimulate and sustain economic growth in the long term. Stock markets can support economic growth by processing information so as to allocate the economy's capital efficiently. Lower stock prices raise the cost of capital to firms that are poorly-run, reduce stock options compensation to under-performing managers, set a barrage of corporate governance mechanisms in motion, and provide feedback to managers to help them avoid further mistakes.

The results surveyed here suggest that simply having a stock market per se is unlikely to either stimulate or sustain economic growth. This is because stock markets allocate capital poorly unless they are teeming with informed investors, who gather and process information about companies and use this to undertake profitable risk arbitrage.

Stock returns in many low-income economies, including many economies in transition, tend to move very synchronously. That is, the stock markets in these countries do little to channel capital towards high quality firms and away from low quality firms. In general, these countries seem to be doing little to improve the functioning of their stock markets. This may be the result of political rent-seeking by economic insiders, who rationally view a well-functioning financial system, and especially a well-functioning stock market, as capable of raising up 
competitors and innovators who threaten the status quo. Consequently, protecting outsiders' property rights not only limits insiders' freedom of action, it threatens their very power and privilege. Granting effective rights to outside shareholders is especially perilous.

There is thus a real danger that some transition economies are replacing economic dictatorship by communist bureaucrats for economic dictatorship by a small clique of politically well-connected, entrenched insiders. These insiders use their "connections" to get rich in the early stages of transition. They then establish pyramidal corporate groups to sidestep poorly functioning markets and expand their control over the economy's resources. Once this control is achieved, the elite undertakes political rent-seeking to lock in their control. This rent-seeking aims to limit outsiders' property rights, to undermine capital markets that might finance upstarts, and to isolate the economy from foreign capital and competition. It induces capital misallocation, prolonged slow growth, and a lack of upward economic mobility for late comers.

Consequently, the rise of politically connected oligarchs and their current construction of pyramidal corporate groups in many transition economies is a cause for deep concern. Once large corporate pyramid groups become entrenched, reversing the economic entrenchment that hinders economic growth will be very difficult.

Finally, economic openness in general, and openness to financial flows in particular, are ways of circumventing these problems. Local competitors and innovators can obtain foreign financial backing, and foreign competitors can enter the local market. Under these circumstances, rent-seeking to undermine the local financial system is, at best, pointless to insiders. Although free capital flow is often condemned as a source of macroeconomic instability, protectionism in finance has the even more unattractive consequences discussed above. Transition economies should conduct responsible macroeconomic and financial policies 
William Davidson Institute Working Paper 417

to avoid financial crises. Barriers against global financial markets are probably very expensive prophylactics. 


\section{References}

Acemoglu, Daron, Simon Johnson, and James A. Robinson, 2001, "The Colonial Origins of Comparative Development: an Empirical Investigation,” American Economics Review, Vol. 91, No. 5, (Dec), pp. $1369-1401$

Almeida, Heitor, and Daniel Wolfenzon. (2003), 'The effect of external finance on the equilibrium allocation of capital', Stern School of Business Working Paper, Department of Finance, New York University.

Bebchuk, Lucien, Reinier Kraakman, and George Triantis. (2000). 'Stock pyramids, crossownerhsip, and dual class equity: The mechanisms and agency costs of separating control from cash-flow rights', in Morck R. (ed.), Concentrated Corporate Ownership, Chicago: National Bureau of Economic Research Conference Volume, University of Chicago Press.

Beck, T., N. Loayza, and R. Levine. (2000). 'Finance and the sources of growth', Journal of Financial Economics, 58, pp. 261-300.

Beny, Laura. (2000). A Comparative Empirical Investigation of Agency and Market Theories of Insider Trading, Harvard Law School Doctoral Dissertation.

Breusch, T. S., and A. Pagan. (1980). 'The Lagrange multiplier test and its applications to model specification in econometrics', The Review of Economic Studies, 47, pp. 239-53.

Bushman, R., J. Piotroski, and A. Smith. (2002), 'What determines corporate transparency?', University of North Carolina Working Paper. 
Chang, James, Tarun Khanna, and Krishna Palepu. (2000), 'Analyst activity around the world', Harvard Business School Working Paper.

Collins, Daniel W.; S.P. Kothari; and Judy Rayburn. (1987) "Firm Size and the Information Content of Prices With Respect to Earnings." Journal of Accounting and Economics 9: $111-138$.

Collins, Daniel W.; and S.P. Kothari. (1989) “An Analysis of Intertemporal and Cross-Sectional Determinants of Earnings Response Coefficients." Journal of Accounting and Economics 11: $143-181$.

De Long, J. B., A. Shleifer, L. H. Summers, and R. J. Waldmann. (1989). 'The size and incidence of the losses from noise trading', Journal of Finance, 44, pp. 681-96.

De Long, J. B., A. Shleifer, L. H. Summers, and R. J. Waldmann. (1990). 'Noise trader risk in financial markets', Journal of Political Economy, 98, pp. 703-38.

Durnev, Art, Randall Morck, and Bernard Yeung. (2000), 'Does firm-specific information in stock prices guide capital allocation?', National Bureau of Economic Research Working Paper No. 8093.

Durnev, Art, Randall Morck, Bernard Yeung, and Paul Zarowin. (2003). 'Does greater firmspecific return variation mean more or less informed stock pricing?', Journal of Accounting Research, forthcoming.

Durnev, Art, Randall Morck, and Bernard Yeung. (2004). 'Value enhancing capital budgeting and firm-specific stock returns variation', Journal of Finance, forthcoming. 
Dyck, Alexander, and Luigi Zingales. (2002). 'The corporate governance role of the media,' in Islam, R. (ed.), The Right to Tell: The Role of Mass Media in Economic Development, Washington, DC: The World Bank, 2002.

Engerman, Stanley, and Kenneth Sokoloff. (1997). 'Factor endowments, institutions, and differential paths of growth Among New World Economies: a View from Economic Historians of the United States', in Haber, S. (ed.), How Latin America Fell Behind, Stanford, CA: Stanford University Press.

Fox, Merritt, Art Durnev, Randall Morck, and Bernard Yeung. (2003). ‘Law, share price accuracy and economic performance, Michigan Law Review, 102, forthcoming.

French, Kenneth R., and Richard Roll. (1986). 'Stock return variances: The arrival of information and the reaction of traders', Journal of Financial Economics, 17, pp. 5-26.

Grossman, Sanford. (1976). 'On the efficiency of competitive stock markets where traders have diverse information', Journal of Finance, 31, pp. 573-85.

Grossman, Sanford, and Joseph Stiglitz. (1980). 'On the impossibility of informationally efficient markets', American Economic Review, 70, pp. 393-408.

Hayek, F. A. von. (1945). 'The use of knowledge in society', American Economic Review, 35, pp. 519-30.

Jensen M., and W. Meckling. (1976). 'Theory of the firm: Managerial behavior, agency costs and ownership structure', Journal of Financial Economics 3, 305-60.

Johnson, Simon, Rafael La Porta, Florencio Lopez-De-Silanes, and Andrei Shleifer. (2000). 'Tunneling', American Economic Review, 90, pp. 22-27. 
King, Robert, and Ross Levine. (1993). 'Finance and growth: Schumpeter might be right', Quarterly Journal of Economics, 153, pp. 717-38.

King, R., and R. Levine. (1994). 'Capital fundamentalism, economic development, and economic growth', Carnegie-Rochester Conference Series on Public Policy, 40, pp. 25992.

La Porta, R., F. Lopez-de-Silanes, A. Shleifer, and R. W. Vishny. (1997). 'Legal determinants of external finance', Journal of Finance, 52, pp. 1131-49.

La Porta, R., F. Lopez de-Silanes, A. Shleifer, and R.W. Vishny. (1998). 'Law and finance', Journal of Political Economy, 106, pp. 1112-55.

La Porta, R., F. Lopez de-Silanes and A. Shleifer. (1999). "Corporate ownership around the world,' Journal of Finance, 54, pp. 471-517.

La Porta, R., F. Lopez de-Silanes, and A. Shleifer. (2000), 'Government ownership of banks', National Bureau of Economic Research Working Paper No. 7620.

La Porta, R., F. Lopez-de-Silanes, and Zamarripa, G. (2001), 'Soft lending and hard landing: Related lending in Mexico', Yale School of Management Working Paper.

Levine, Ross. (1997). 'Financial development and economic growth: Views and agenda', Journal of Economic Literature, 35, pp. 688-726.

Levine, Ross. (2002). 'Bank-based or market-based financial systems: Which is better?', Journal of Financial Intermediation, 11, pp. 1-30. 
Levine, Ross, and Sara Zervos. (1998). 'Stock markets, banks, and economic growth', American Economic Review, 88, pp. 537-58.

Morck, R., A. Shleifer, and R. Vishny. (1988). ‘Management ownership and corporate performance: An empirical analysis', Journal of Financial Economics, 20, pp. 293-315.

Morck, Randall. (1995). 'The economics of concentrated ownership', Canadian Business Law Journal, 26, pp. 63-85.

Morck, R., and Nakamura, M. (1999). 'Banks and corporate control in Japan', Journal of Finance, 54, pp. 319-39.

Morck, Randall, David Stangeland, and Bernard Yeung. (2000). 'Inherited wealth, corporate control, and economic growth", in Morck, R. (ed.), Concentrated Corporate Ownership, Chicago, IL: The University of Chicago Press and National Bureau of Economic Research Working Paper No. 6814 (1998).

Morck, Randall, Bernard Yeung, and Wayne Yu. (2000). 'The information content of stock markets: Why do emerging markets have synchronous stock price movements?', Journal of Financial Economics, 59, pp. 215-238

Morck, Randall, Daniel Wolfenzon, and Bernard Yeung. (2003), 'Economic entrenchment and economic growth', Stern School of Business Working Paper, Department of Finance, New York University.

Morck, Randall, Kan Li, Fan Yang, and Bernard Yeung. (2004). 'Firm-specific variation and openness in emerging markets', Review of Economics and Statistics, forthcoming 
Morck, Randall, and Bernard Yeung. (2003). 'Family control and the rent-seeking society', Entrepreneurship: Theory and Practice, forthcoming.

Olson, Mancur Jr. 1982. The Rise and Decline of Nations. Yale University Press. New Haven

Rajan, R., and L. Zingales. (2003). 'The great reversals: The politics of financial development in the $20^{\text {th }}$ Century', Journal of Financial Economics, 69, pp. 5-50.

Roll, R. (1988). 'R², Journal of Finance, 43, pp. 541-66.

Shleifer, Andrei, and R.W. Vishny. (1986). 'Large shareholders and corporate control', Journal of Political Economy, 95, pp. 461-88.

Shleifer, A., and R.W. Vishny. (1997). 'The limits of arbitrage,' Journal of Finance, 52, pp. 3555.

Sokoloff, Kenneth L., and Stanley L. Engerman. (2000). 'Institutions, factor endowments, and paths of development in the New World', Journal of Economic Perspectives, 14, pp. 21732.

Veblen, Thorstein. (1899). The Theory of the Leisure Class; An Economic Study in the Evolution of Institutions, London, UK: Macmillan \& Co.

Veblen, Thorstein. (1904). The Theory of Business Enterprise, New York, NY: C. Scribner's Sons.

Veblen, Thorstein. (1923). Absentee Ownership and Business Enterprise in Recent Times, New York, NY: A. M. Kelley. 
William Davidson Institute Working Paper 417

Wurgler, Jeffrey. (2000). 'Financial markets and the allocation of capital', Journal of Financial Economics, 58, pp. 187-214. 


\section{Table I}

\section{Definitions of Main Variables Used In GDP Growth and Productivity Growth Regressions}

The sample consists of 53 countries. We drop country-year observations if the stock price synchronicity measure is based on fewer than 11 firms. The final sample includes the following countries: Argentina, Australia, Austria, Bangladesh, Belgium, Brazil, Canada, Chile, China, Colombia, Czech Republic, Denmark, Ecuador, Egypt, Finland, France, Germany, Greece, Hong Kong, Hungary, India, Indonesia, Ireland, Israel, Italy, Japan, Kenya, Korea (South), Luxembourg, Malaysia, Mexico, Morocco, Netherlands, New Zealand, Norway, Pakistan, Peru, Philippines, Poland, Portugal, Romania, Russia, Singapore, South Africa, Spain, Sweden, Switzerland, Thailand, Turkey, United Kingdom, United States, Venezuela, and Zimbabwe.

\begin{tabular}{|c|c|c|}
\hline Variable & & Definition and Source \\
\hline Panel A: GDP an & oroductivi & y growth variables \\
\hline GDP growth & $\triangle G D P$ & $\begin{array}{l}\text { Growth rate in real Gross Domestic Product per capita, constructed } \\
\text { annually from } 1991 \text { through } 2000 \text {. Source: } 2002 \text { Worldbank's World } \\
\text { Development Indicators dataset. }\end{array}$ \\
\hline $\begin{array}{l}\text { Productivity } \\
\text { growth }\end{array}$ & $\triangle P R O D$ & $\begin{array}{l}\text { Growth rate in real Gross Domestic Product per capita }-0.3^{*} \text { real per } \\
\text { capita growth rate in fixed capital stock, constructed annually from } \\
1991 \text { through } 2000 \text {. The fixed capital stock is calculated using a } \\
\text { recursive formula described in the text. Source: } 2002 \text { Worldbank's } \\
\text { World Development Indicators dataset and Penn World Tables } 6.1 \text {. }\end{array}$ \\
\hline Panel B. Stock F & urns Syn & hronicity Measure \\
\hline $\begin{array}{l}\text { Stock price } \\
\text { synchronicity }\end{array}$ & $Y$ & $\begin{array}{l}\text { Logarithmic transformation of stock price synchronicity measured by } \\
\text { the average percent of total weekly firm-level return variation } \\
\text { explained by local and U.S. value-weighted market indexes, } \\
\text { constructed annually from } 1990 \text { through } 1999 \text {. Source: DataStream } \\
\text { and CRSP. }\end{array}$ \\
\hline Panel C. Contr & & \\
\hline Market Size & $L N$ & $\begin{array}{l}\text { Log of the number of stocks used to calculate the stock price } \\
\text { synchronicity measure. }\end{array}$ \\
\hline Initial GDP & & Log of real per capita GDP, constructed annually from 1990 through \\
\hline & $G D P I$ & $\begin{array}{l}\text { 1999. Source: } 2002 \text { Worldbank's World Development Indicators } \\
\text { dataset. }\end{array}$ \\
\hline Government size & GOV & $\begin{array}{l}\text { Log of the share of government expenditure in GDP, constructed } \\
\text { annually from } 1990 \text { through 1999. Source: } 2002 \text { Worldbank's World } \\
\text { Development Indicators dataset. }\end{array}$ \\
\hline Trade Openness & & Log of trade share in GDP, constructed annually from 1990 through \\
\hline & OPEN & $\begin{array}{l}\text { 1999. It is defined as the sum of exports and imports as a share of } \\
\text { GDP. Source: } 2002 \text { Worldbank's World Development Indicators } \\
\text { dataset. }\end{array}$ \\
\hline Inflation & $I N F L$ & $\begin{array}{l}\text { Log of one plus inflation rate where the inflation rate is defined as the } \\
\text { log difference of Consumer Price Index, constructed annually from } \\
1990 \text { through 1999. Source: } 2002 \text { World Development Indicators } \\
\text { dataset. }\end{array}$ \\
\hline $\begin{array}{l}\text { Market } \\
\text { Capitalization }\end{array}$ & $M C A P$ & $\begin{array}{l}\text { Log of the value of all listed shares over GDP, constructed annually } \\
\text { from } 1990 \text { through 1999. Source: } 2002 \text { World Development Indicators } \\
\text { dataset. }\end{array}$ \\
\hline Bank Credit & CREDIT & $\begin{array}{l}\text { Log of the value of credit by deposit money banks and other financial } \\
\text { institutions to the private sector over GDP, constructed annually from } \\
1990 \text { through } 1999 \text {. Source: } 2002 \text { World Development Indicators } \\
\text { dataset. }\end{array}$ \\
\hline Rule of Law & $L A W$ & Measure of law and order tradition of a country, annual from 1990 \\
\hline
\end{tabular}


William Davidson Institute Working Paper 417

Educational

Expenses through 1999. This variable ranges from 1 (weak law and order tradition) to 6 (strong law and order tradition). Source: International Country Risk Guide.

Log of public expenditure on education over GDP, constructed annually from 1990 through 1999. Source: 2002 World Development Indicators dataset. 


\section{Table II}

\section{Relationship between Economic Growth and Logarithmic Transformation of Stock Price Synchronicity}

This table reports the results of country-fixed, time-random regressions of GDP growth on logarithmic transformation of stock price synchronicity and control variables. Numbers in parentheses are probability levels at which the null hypothesis of a zero coefficient can be rejected. Coefficients significant at $10 \%$ or better (2-tailed test) are in boldface. We drop country-year observations if the stock price synchronicity measure is based on fewer than 11 firms. Refer to Table 1 for variables definitions.

\begin{tabular}{|c|c|c|c|c|c|}
\hline $\begin{array}{r}\text { Specification } \\
\text { Dependent variable }\end{array}$ & & \multicolumn{4}{|c|}{$\begin{array}{l}\text { GDP growth, } \\
\qquad G D P\end{array}$} \\
\hline Stock price synchronicity & $Y$ & $\begin{array}{r}-0.009 \\
(0.00)\end{array}$ & $\begin{array}{l}-0.012 \\
(0.00)\end{array}$ & $\begin{array}{l}-0.010 \\
(0.00)\end{array}$ & $\begin{array}{r}-0.006 \\
(0.07)\end{array}$ \\
\hline Market Size & $L N$ & $\begin{array}{l}\mathbf{0 . 0 1 6} \\
(0.01)\end{array}$ & $\begin{array}{l}0.016 \\
(0.01)\end{array}$ & $\begin{array}{l}-0.006 \\
(0.47)\end{array}$ & $\begin{array}{l}0.001 \\
(0.89)\end{array}$ \\
\hline Initial GDP & $G D P I$ & -0.159 & -0.220 & -0.229 & -0.230 \\
\hline & & $(0.00)$ & $(0.00)$ & $(0.00)$ & $(0.00)$ \\
\hline Inflation & INFL & - & $\begin{array}{l}0.021 \\
(0.39)\end{array}$ & $\begin{array}{l}0.001 \\
(0.98)\end{array}$ & $\begin{array}{r}-0.011 \\
(0.70)\end{array}$ \\
\hline Trade Openness & OPEN & - & $\begin{array}{l}\mathbf{0 . 0 8 1} \\
(0.00)\end{array}$ & $\begin{array}{l}0.052 \\
(0.00)\end{array}$ & $\begin{array}{l}\mathbf{0 . 0 8 8} \\
(0.00)\end{array}$ \\
\hline \multirow[t]{2}{*}{ Government size } & GOV & - & 0.039 & 0.041 & 0.018 \\
\hline & & & $(0.09)$ & $(0.05)$ & $(0.59)$ \\
\hline \multirow[t]{2}{*}{ Bank Credit } & CREDIT & - & - & -0.033 & -0.038 \\
\hline & & & & $(0.00)$ & $(0.00)$ \\
\hline \multirow[t]{2}{*}{ Market Capitalization } & $M C A P$ & - & - & 0.035 & 0.026 \\
\hline & & & & $(0.00)$ & $(0.00)$ \\
\hline \multirow[t]{2}{*}{ Rule of Law } & $L A W$ & - & - & 0.003 & 0.003 \\
\hline & & & & $(0.22)$ & $(0.18)$ \\
\hline \multirow[t]{2}{*}{ Educational Expenses } & $E D U C$ & - & - & - & -0.017 \\
\hline & & & & & $(0.25)$ \\
\hline & & 0.331 & 0.392 & 0.538 & 0.628 \\
\hline \multirow{2}{*}{$\begin{array}{r}\text { Wald test statistics of overall } \\
\text { significance }\end{array}$} & & 197.46 & 497.76 & 368.46 & 616.75 \\
\hline & & $(0.00)$ & $(0.00)$ & $(0.00)$ & $(0.00)$ \\
\hline Number of country-year observations & & 454 & 440 & 368 & 241 \\
\hline
\end{tabular}




\section{Table III}

\section{Relationship between Productivity Growth and Logarithmic Transformation of Stock Price Synchronicity}

This table reports the results of country-fixed, time-random regressions of productivity growth on logarithmic transformation of stock price synchronicity and control variables. Numbers in parentheses are probability levels at which the null hypothesis of a zero coefficient can be rejected. Coefficients significant at $10 \%$ or better (2-tailed test) are in boldface. We drop country-year observations if the stock price synchronicity measure is based on fewer than 11 firms. We exclude countries whose share of investment in GDP is missing for any of the years from 1960 through 2000 in Penn World Tables 6.1. Refer to Table 1 for variables definitions.

\begin{tabular}{|c|c|c|c|c|c|}
\hline $\begin{array}{r}\text { Specification } \\
\text { Dependent variable }\end{array}$ & & \multicolumn{4}{|c|}{$\begin{array}{c}\text { Productivity growth, } \\
\triangle P R O D\end{array}$} \\
\hline Stock price synchronicity & $Y$ & $\begin{array}{r}-0.010 \\
(0.00)\end{array}$ & $\begin{array}{l}-\mathbf{- 0 . 0 1 3} \\
(0.00)\end{array}$ & $\begin{array}{l}-0.008 \\
(0.00)\end{array}$ & $\begin{array}{c}-0.005 \\
(0.07)\end{array}$ \\
\hline Market Size & $L N$ & $\begin{array}{l}0.014 \\
(0.03) \\
-0115\end{array}$ & $\begin{array}{l}0.019 \\
(0.00) \\
-0.213\end{array}$ & $\begin{array}{l}-0.006 \\
(0.39) \\
-01108\end{array}$ & $\begin{array}{l}-0.008 \\
(0.33) \\
-0.208\end{array}$ \\
\hline Initial GDP & $G D P I$ & $\begin{array}{l}-0.145 \\
(0.00)\end{array}$ & $\begin{array}{r}-0.213 \\
(0.00)\end{array}$ & $\begin{array}{r}-0.198 \\
(0.00)\end{array}$ & $\begin{array}{r}-0.208 \\
(0.00)\end{array}$ \\
\hline Inflation & $I N F L$ & - & $\begin{array}{l}-0.003 \\
(0.92)\end{array}$ & $\begin{array}{l}0.007 \\
(0.76)\end{array}$ & $\begin{array}{l}-0.009 \\
(0.72)\end{array}$ \\
\hline Trade Openness & OPEN & - & $\begin{array}{l}\mathbf{0 . 0 8 3} \\
(0.00)\end{array}$ & $\begin{array}{l}\mathbf{0 . 0 6 0} \\
(0.00)\end{array}$ & $\begin{array}{l}\mathbf{0 . 1 0 0} \\
(0.00)\end{array}$ \\
\hline Government size & $G O V$ & - & $\begin{array}{l}\mathbf{0 . 0 4 3} \\
(0.04)\end{array}$ & $\begin{array}{l}\mathbf{0 . 0 5 7} \\
(0.00)\end{array}$ & $\begin{array}{l}0.021 \\
(0.44)\end{array}$ \\
\hline Bank Credit & CREDIT & - & - & $\begin{array}{r}-0.032 \\
(0.00)\end{array}$ & $\begin{array}{l}-0.037 \\
(0.00)\end{array}$ \\
\hline Market Capitalization & $M C A P$ & - & - & $\begin{array}{l}\mathbf{0 . 0 3 2} \\
(0.00)\end{array}$ & $\begin{array}{l}\mathbf{0 . 0 2 5} \\
(0.00)\end{array}$ \\
\hline Rule of Law & $L A W$ & - & - & $\begin{array}{l}0.002 \\
(0.35)\end{array}$ & $\begin{array}{l}0.003 \\
(0.23)\end{array}$ \\
\hline Educational Expenses & $E D U C$ & - & - & - & $\begin{array}{l}0.003 \\
(0.81)\end{array}$ \\
\hline Regression $\mathrm{R}^{2}$ & & 0.257 & 0.343 & 0.514 & 0.623 \\
\hline $\begin{array}{r}\text { Wald test statistics of overall } \\
\text { significance }\end{array}$ & & $\begin{array}{r}123.52 \\
(0.00)\end{array}$ & $\begin{array}{r}178.49 \\
(0.00)\end{array}$ & $\begin{array}{l}451.08 \\
(0.00)\end{array}$ & $\begin{array}{r}298.60 \\
(0.00)\end{array}$ \\
\hline Number of country-year observations & & 407 & 393 & 348 & 230 \\
\hline
\end{tabular}


Figure 1

H. J. Heinz stock and the S\&P 500 index over the five trading days leading up to Tuesday, Dec. 71999

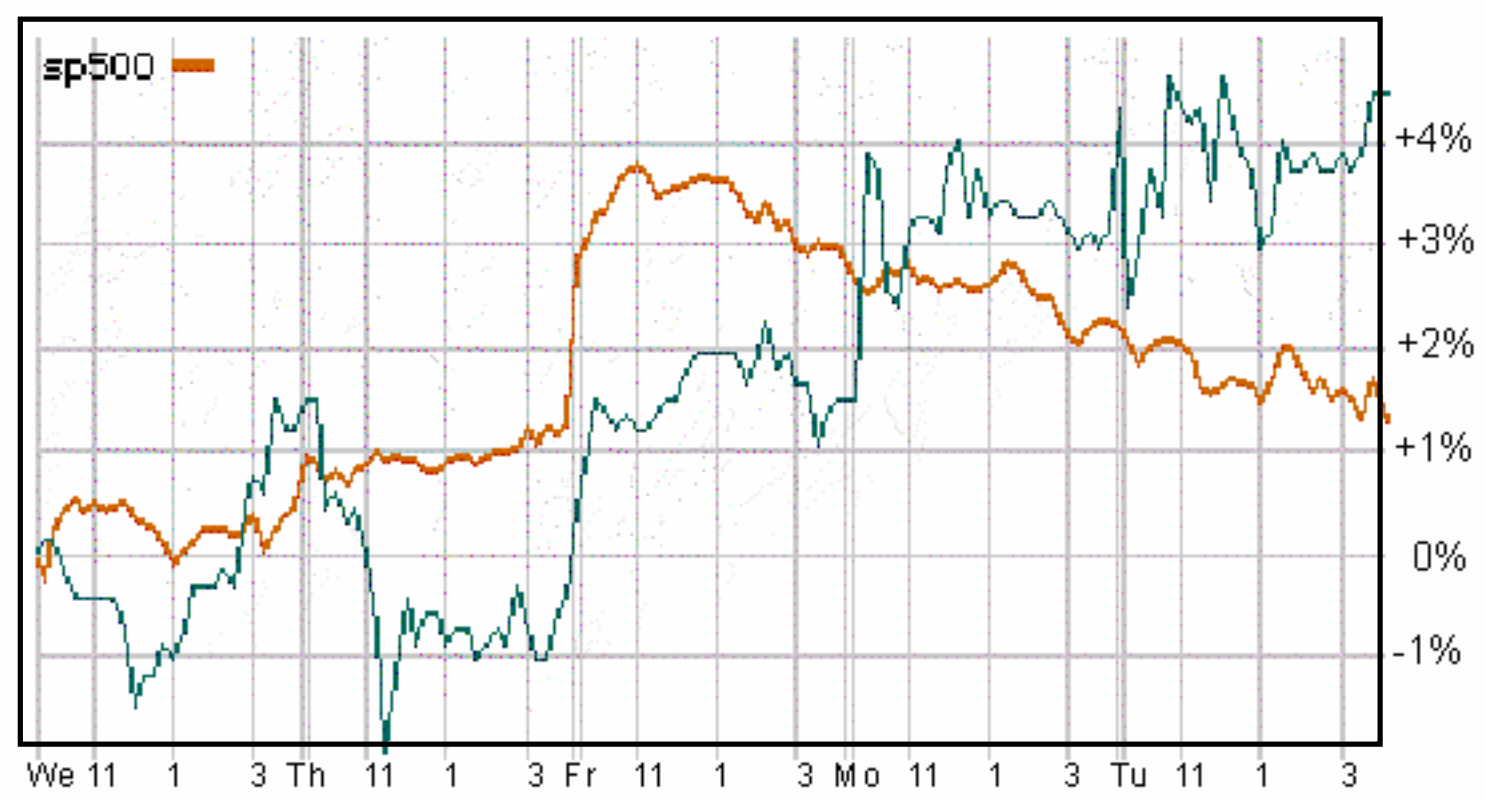


Figure 2 Stock price synchronicity in various countries

Panel A. Stock price synchronicity measured by the average percent of total biweekly firm-level return variation in 1995 explained by local and U.S. valueweighted market indexes as in Morck, Yeung, and Yu (2000). Stock returns and indexes include dividend payments, and are obtained from DataStream.

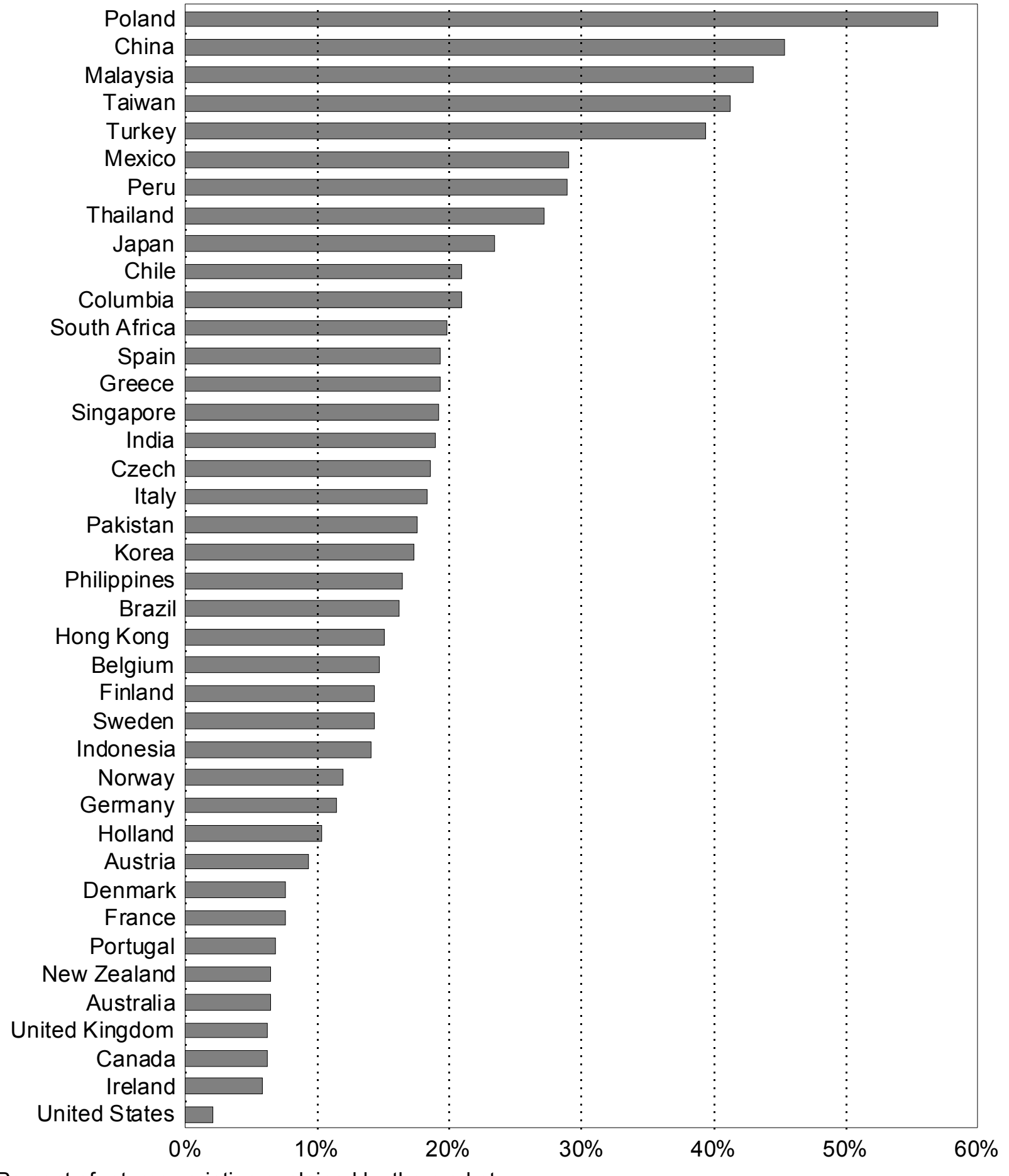

Percent of returns variation explained by the market 
Figure 2

Panel B. Stock price synchronicity measured by the average fraction of stock prices moving in the same direction during an average week in 1995 as in Morck, Yeung, and Yu (1995). Stock prices that do not move during a week are excluded from the average for that week. Price movements are adjusted for dividend payments, and are based on DataStream total returns.

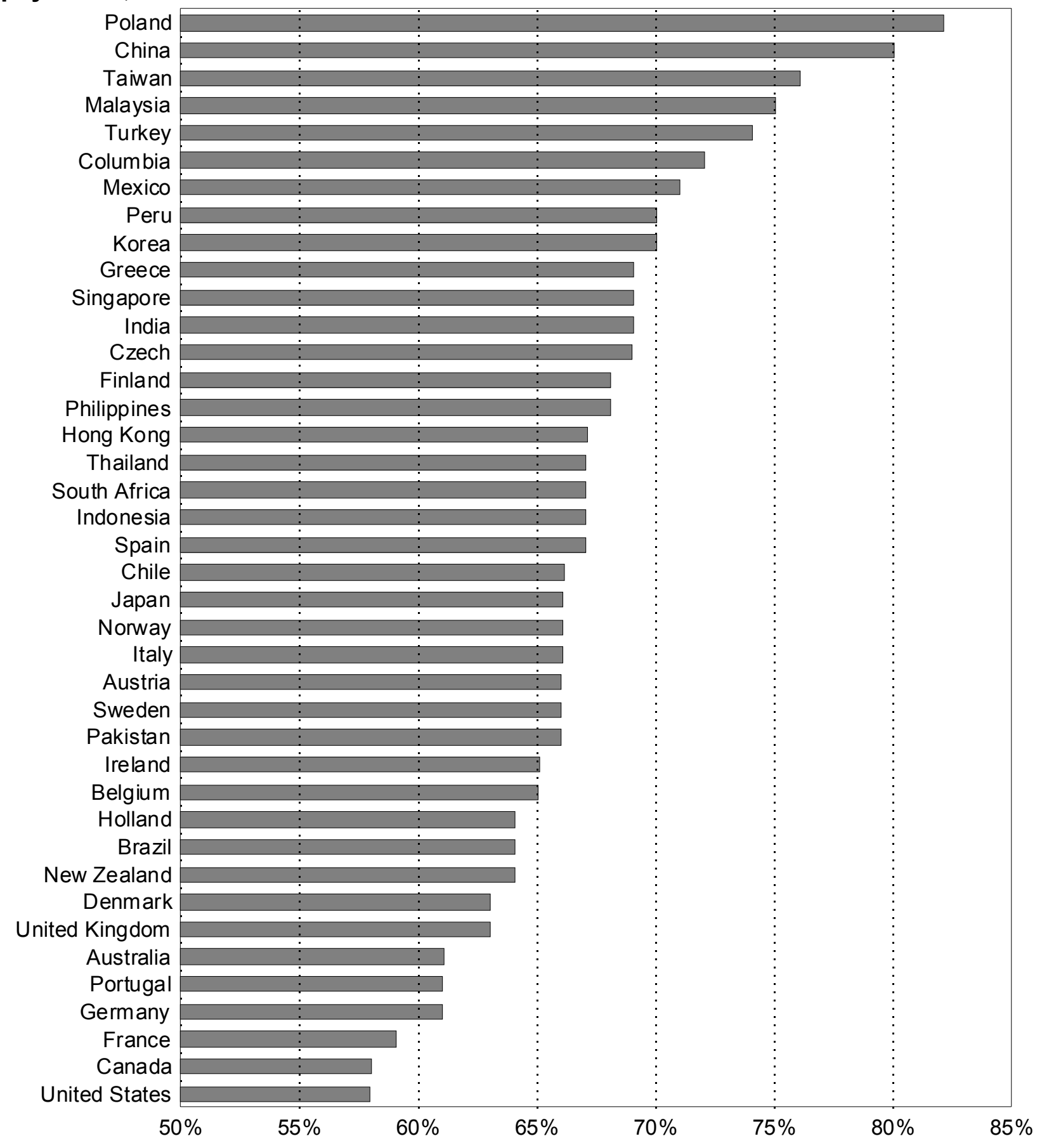

Percent of stocks moving in the same direction by country 
Figure 3

Stock Return Synchronicity and Good Government Index as in Morck, Yeung, and Yu (2000)

The Good Government Index plotted against stock return synchronicity measured by the average fraction of individual biweekly returns variation explained by market indices. Each observation is for one country. Data are for 1995.

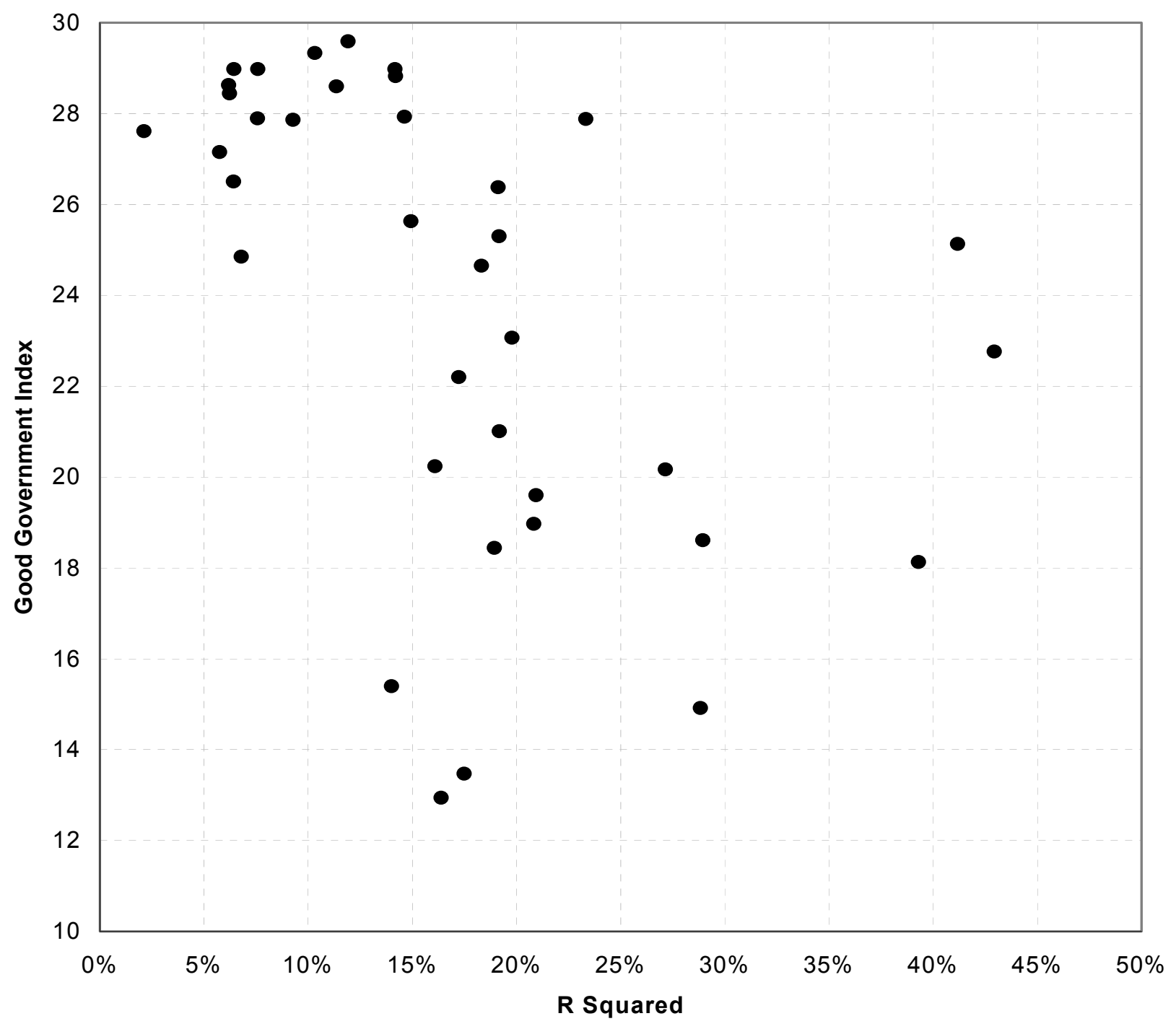


Figure 4

Stock Return Synchronicity and the Decomposition of Returns Variation as in Morck, Yeung, and Yu (2000)

Average stock return variation decomposed into a systematic component, $\sigma_{m, i}^{2}$, and a firm-specific stock component, $\sigma_{\varepsilon, i}^{2}$, plotted against stock return synchronicity measured by the average fraction of individual biweekly returns variation explained by market indices. $\sigma_{m, i}^{2}$ is the average variation in country $\mathbf{j}$ stock returns that is explained by market factors. $\sigma_{\varepsilon, j}^{2}$ is the average firm-specific variation in country $\mathbf{j}$ stock returns. Each observation is for one country. Data are for 1995.

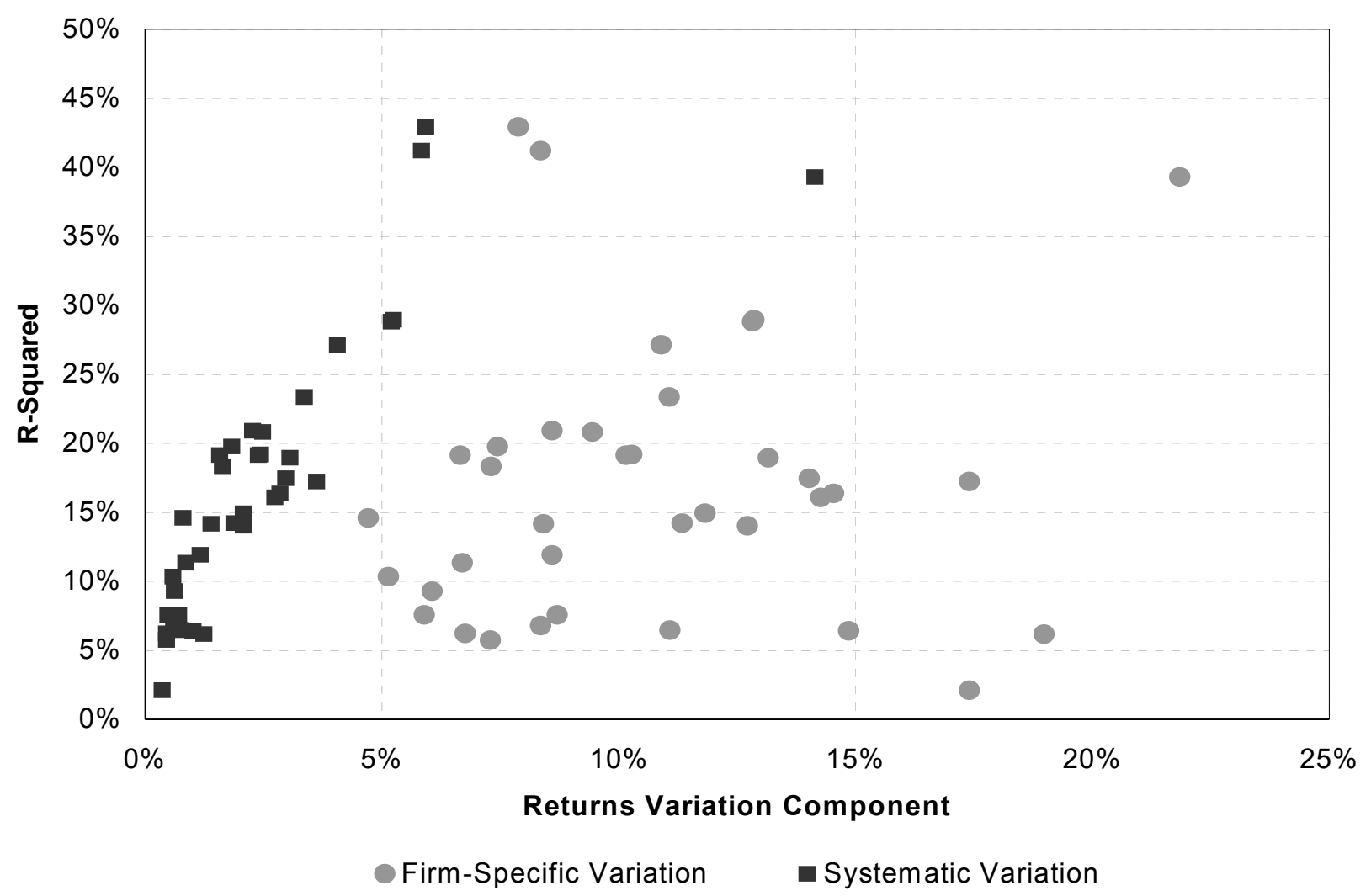


Figure 5

Good Government and the Decomposition of Returns Variation as in Morck, Yeung, and $\mathrm{Yu}(2000)$

Average stock return variation decomposed into a systematic component, $\sigma_{m, i}^{2}$, and a firm-specific stock component, $\sigma_{\varepsilon, i}^{2}$, plotted against the Good Government Index, which measures the strength of private property rights protection in each country. $\sigma_{m, i}^{2}$ is the average variation in country $\mathbf{j}$ stock returns that is explained by market factors. $\sigma_{\varepsilon, j}^{2}$ is the average firm-specific variation in country $\mathbf{j}$ stock returns. Each observation is for one country. Data are for 1995.

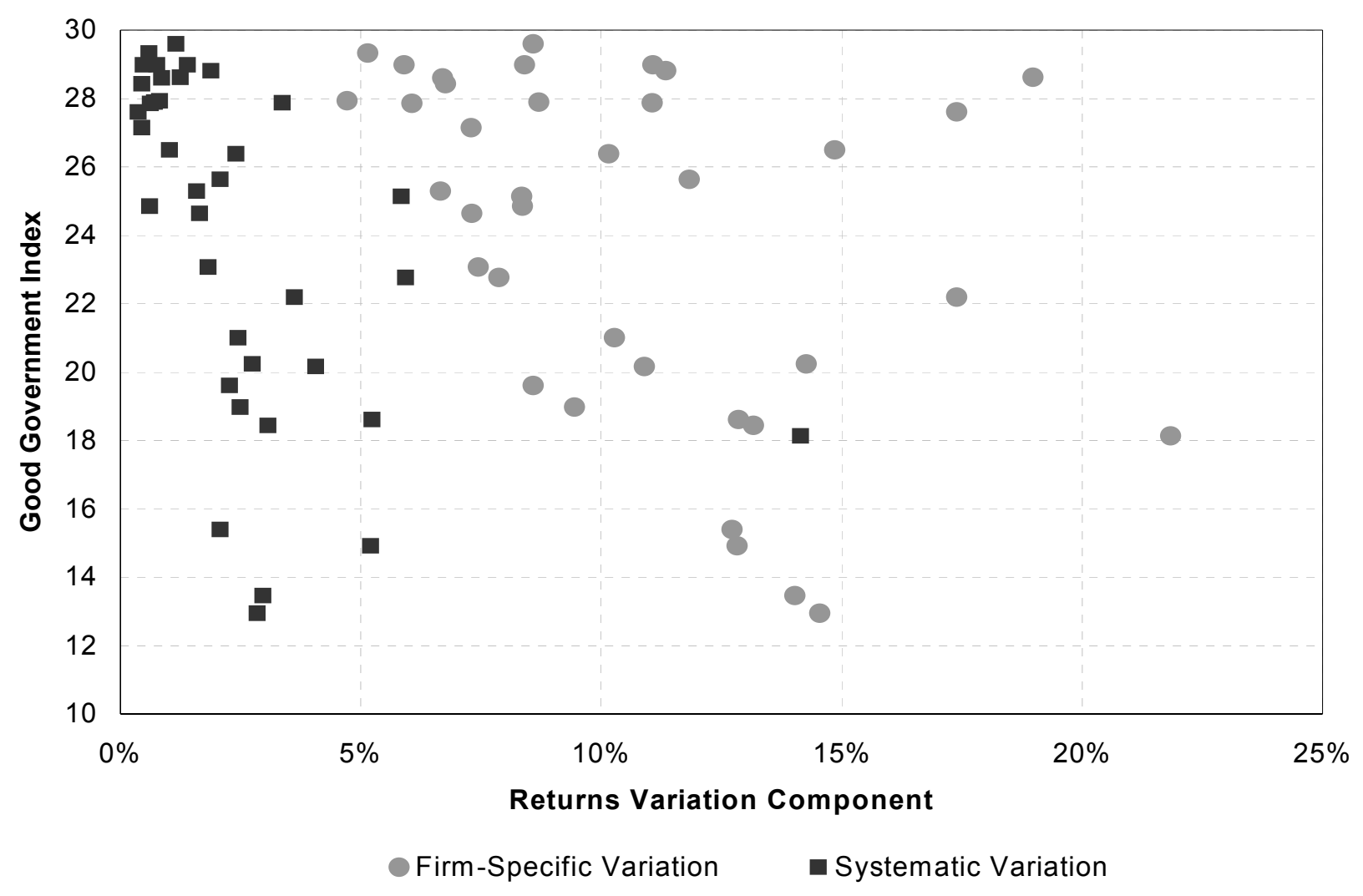


Figure 6

Shareholder Rights and the Decomposition of Returns Variation as in Morck, Yeung, and Yu (2000)

Average stock return variation decomposed into a systematic component, $\sigma_{m, i}^{2}$, and a firm-specific stock component, $\sigma_{\varepsilon, i}^{2}$, plotted against the number of legal rights protecting shareholders in each country. $\sigma_{m, i}^{2}$ is the average variation in country $\boldsymbol{j}$ stock returns that is explained by market factors. $\sigma_{\varepsilon, j}^{2}$ is the average firm-specific variation in country $j$ stock returns. Each observation is for one country. Data are for 1995.

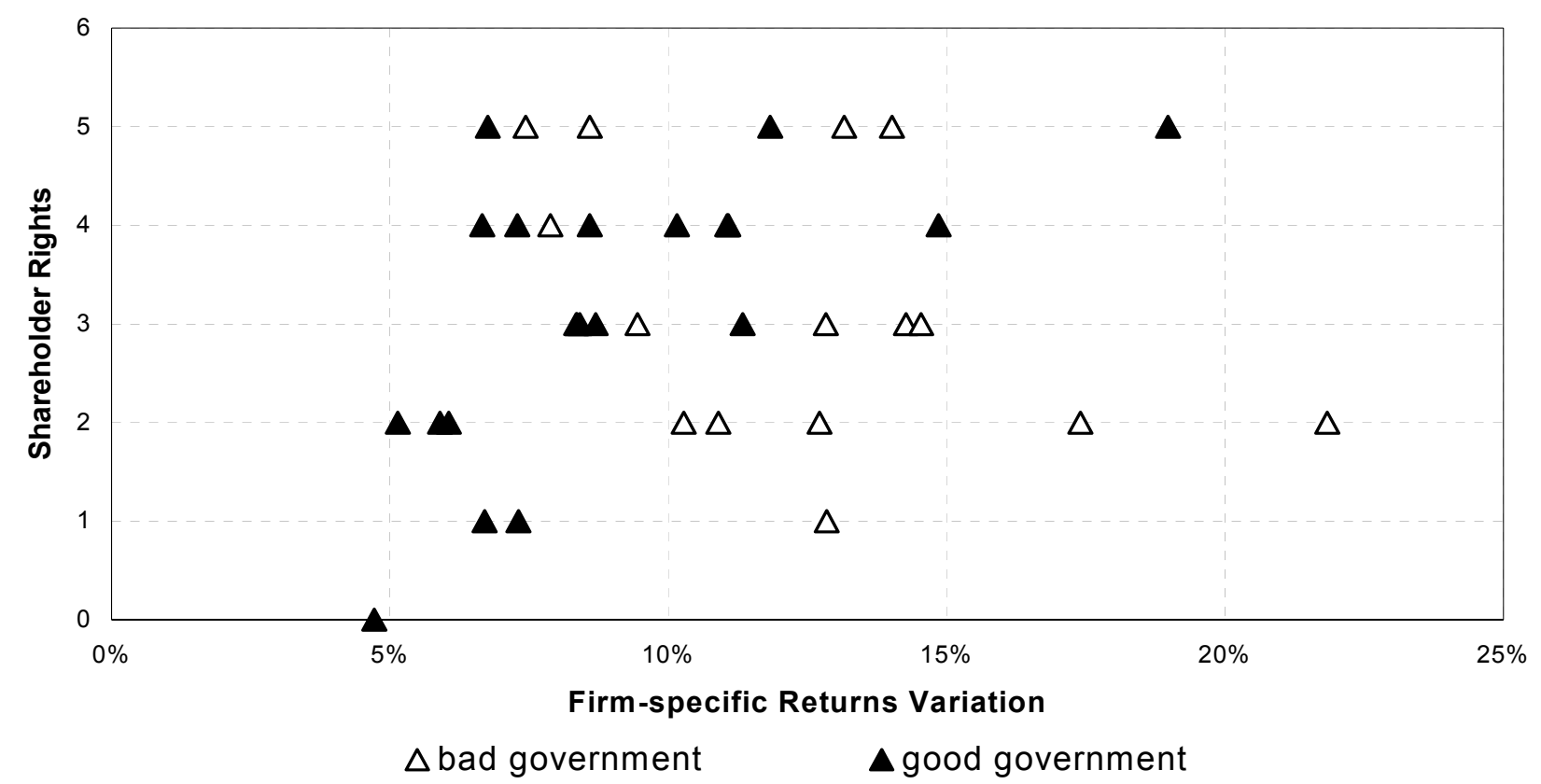


Figure 7

Quality of Capital Allocation and Stock Price Synchronicity.

Stock price synchronicity is measured by the average fraction of stock prices moving in the same direction during an average week in 1995 as in Morck, Yeung, and Yu (2000).

This figure represents 34 countries: Australia, Austria, Belgium, Canada, Chile, Colombia, Denmark, Finland, France, Germany, Greece, Hong Kong, India, Indonesia, Ireland, Italy, Japan, South Korea, Malaysia, Mexico, Netherlands, New Zealand, Norway, Pakistan, Peru, Philippines, Portugal, Singapore, Spain, Sweden, Turkey, United Kingdom, and United States. Quality of capital allocation is determined as in (7), elasticity of capital expenditure with respect to value added (Wurgler (2000)). The straight line has the intercept $\alpha$ and the slope $\beta$ estimated by OLS from regression $\Delta Q_{i}=\alpha+\beta^{\star} f_{i}+e_{i}$, where $Q$ is the quality of capital allocation and $f$ is stock price synchronicity.

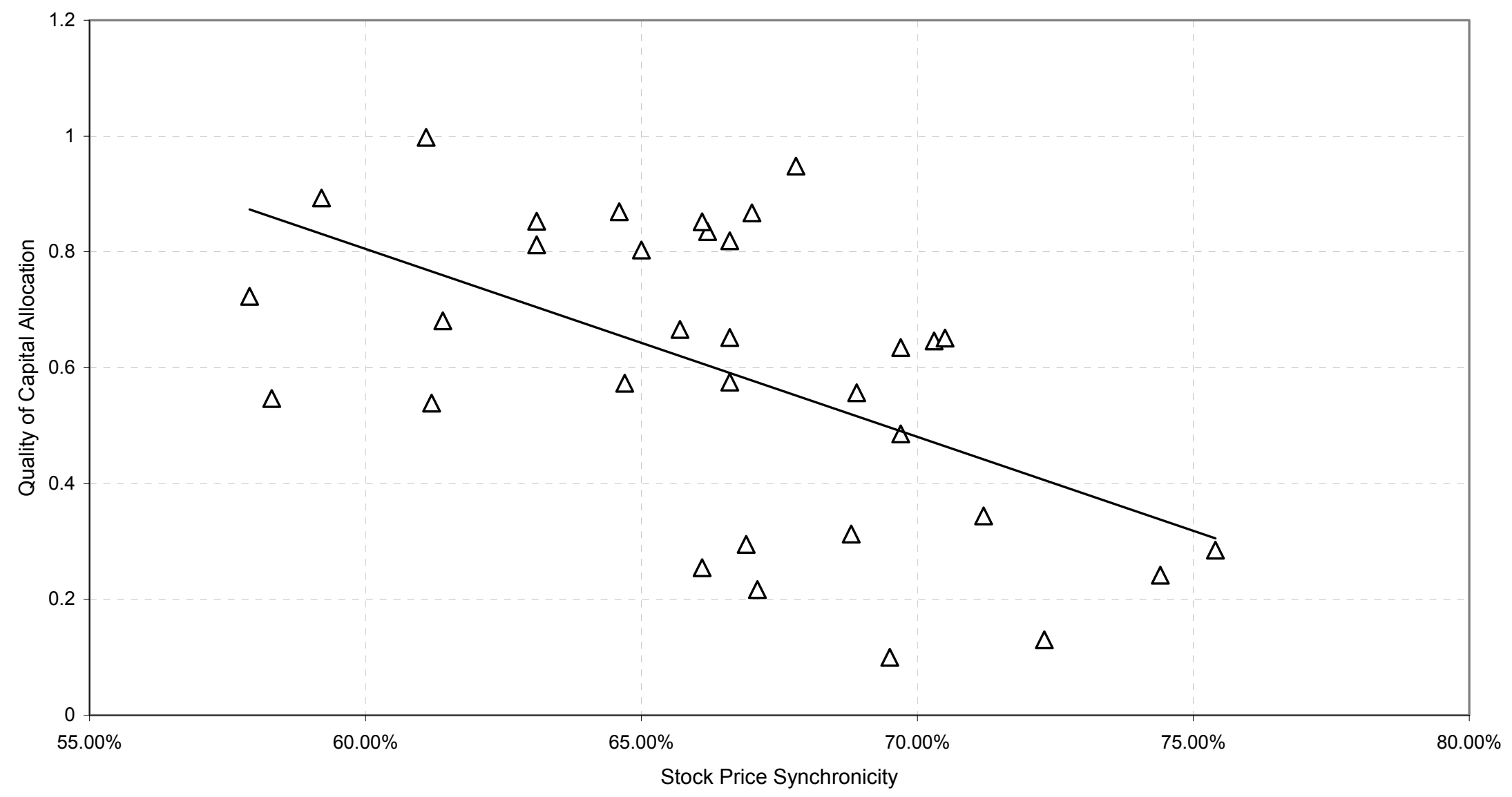




\section{Figure 8}

\section{GDP Growth and Stock Price Synchronicity}

Synchronicity is the log transformation of average fraction of weekly firm-level return variation explained by local and U.S. value-weighted market indexes.

This graph presents the partial regression plot of GDP growth on stock price synchronicity and control variables as in specification 2.3 of Table II. Control variables include country fixed effects. The sample consists of 368 country-year observations (53 countries). We drop country-year observations if the stock price synchronicity measure is based on fewer than 11 firms. The final sample includes the following countries: Argentina, Australia, Austria, Bangladesh, Belgium, Brazil, Canada, Chile, China, Colombia, Czech Republic, Denmark, Ecuador, Egypt, Finland, France, Germany, Greece, Hong Kong, Hungary, India, Indonesia, Ireland, Israel, Italy, Japan, Kenya, Korea (South), Luxembourg, Malaysia, Mexico, Morocco, Netherlands, New Zealand, Norway, Pakistan, Peru, Philippines, Poland, Portugal, Romania, Russia, Singapore, South Africa, Spain, Sweden, Switzerland, Thailand, Turkey, United Kingdom, United States, Venezuela, and Zimbabwe. The straight line has the intercept $\alpha$ and the slope $\beta$ estimated by OLS from regression $\triangle G D P_{i}=\alpha+\beta^{\star} Y_{i}+\gamma Z_{i}+e_{i}$, where $\triangle G D P_{i}$ is the growth in real GDP per capita, $Y_{i}$ is th log transformation of stock price synchronicity, and $Z$ are control variables.

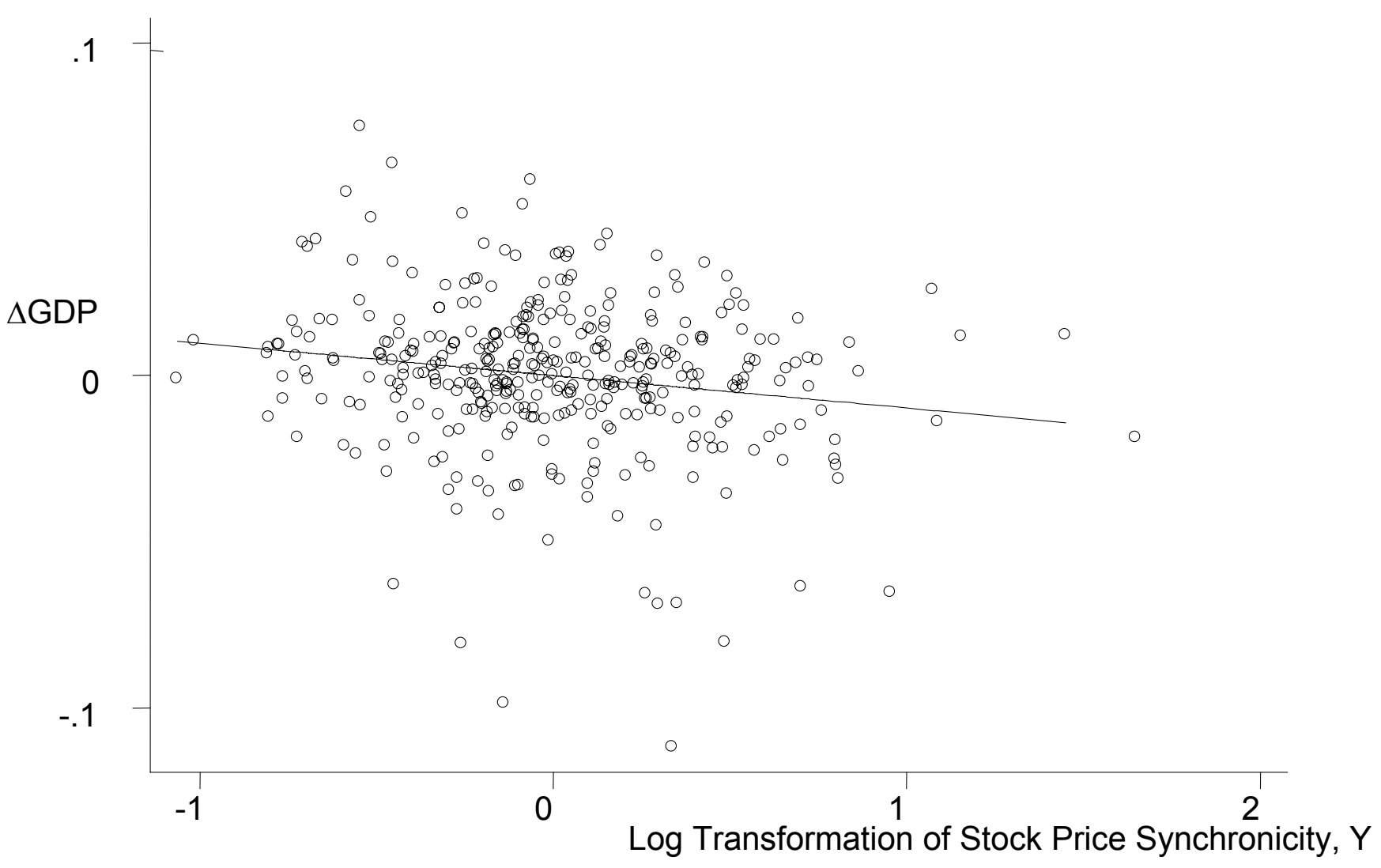


Figure 9: Productivity Growth and Stock Price Synchronicity

Synchronicity is the log transformation of the average fraction of weekly firm-level return variation explained by local and U.S. value-weighted market indexes

This graph presents the partial regression plot of productivity growth on stock price synchronicity and control variables as in specification 3.3 of Table III. Control variables include country fixed effects. The sample consists of 348 country-year observations (53 countries). We drop country-year observations if the stock price synchronicity measure is based on fewer than 11 firms. We exclude countries whose share of investment in GDP is missing for any of the years from 1960 through 2000 in Penn World Tables 6.1. The final sample includes the following countries: Argentina, Australia, Austria, Bangladesh, Belgium, Brazil, Canada, Chile, China, Colombia, Czech Republic, Denmark, Ecuador, Egypt, Finland, France, Germany, Greece, Hong Kong, Hungary, India, Indonesia, Ireland, Israel, Italy, Japan, Kenya, Korea (South), Luxembourg, Malaysia, Mexico, Morocco, Netherlands, New Zealand, Norway, Pakistan, Peru, Philippines, Poland, Portugal, Romania, Russia, Singapore, South Africa, Spain, Sweden, Switzerland, Thailand, Turkey, United Kingdom, United States, Venezuela, and Zimbabwe. The straight line has the intercept $\alpha$ and the slope $\beta$ estimated by OLS from regression $\triangle P R O D_{i}=\alpha+\beta^{\star} Y_{i}+\gamma Z_{i}+e_{i}$, where $\triangle P R O D_{i}$ is productivity growth in real GDP per capita, $Y_{i}$ is th log transformation of stock price synchronicity, and $Z$ are control variables.

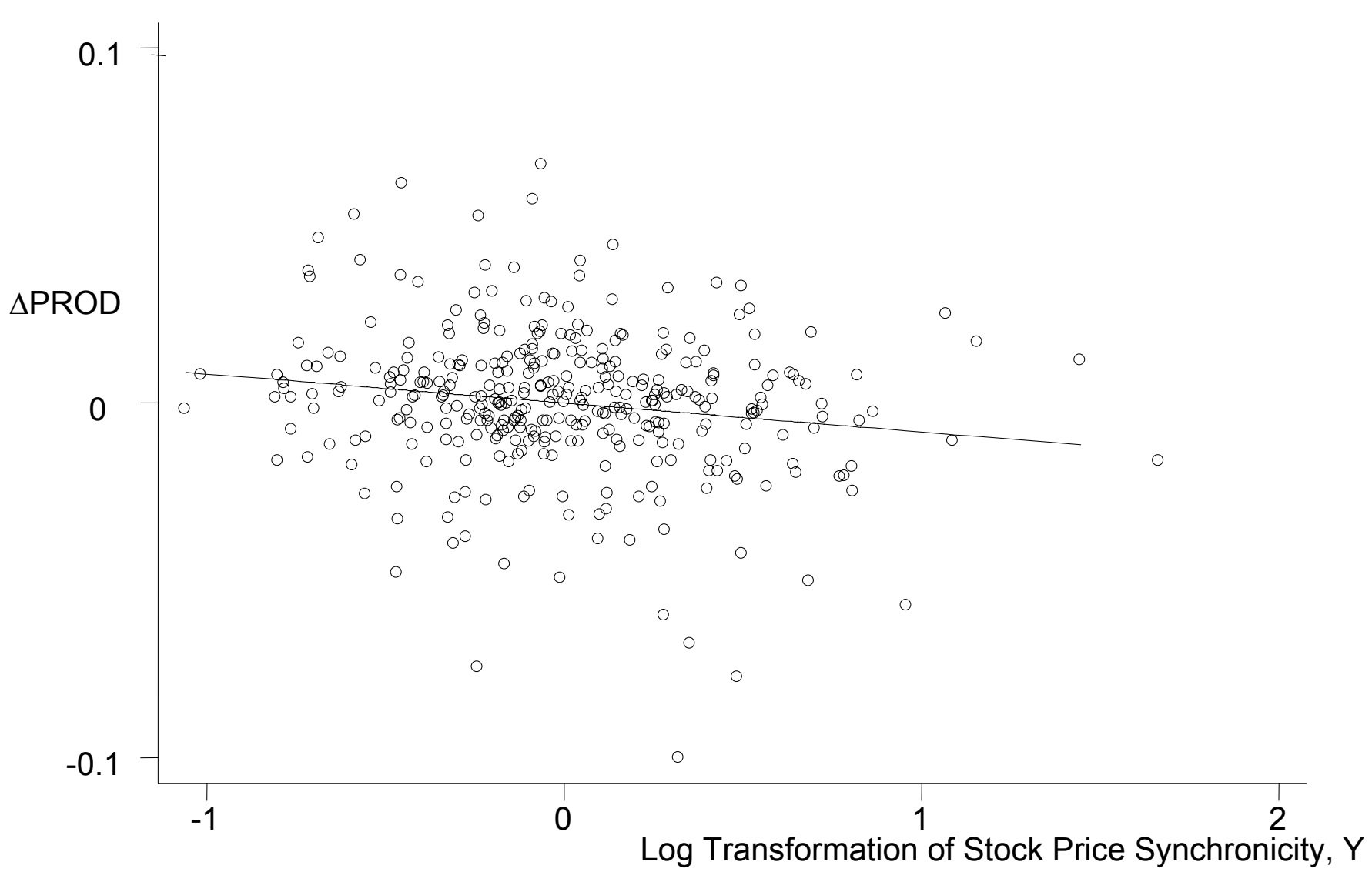


A Stylized Diagram of a Typical Corporate Control Pyramid

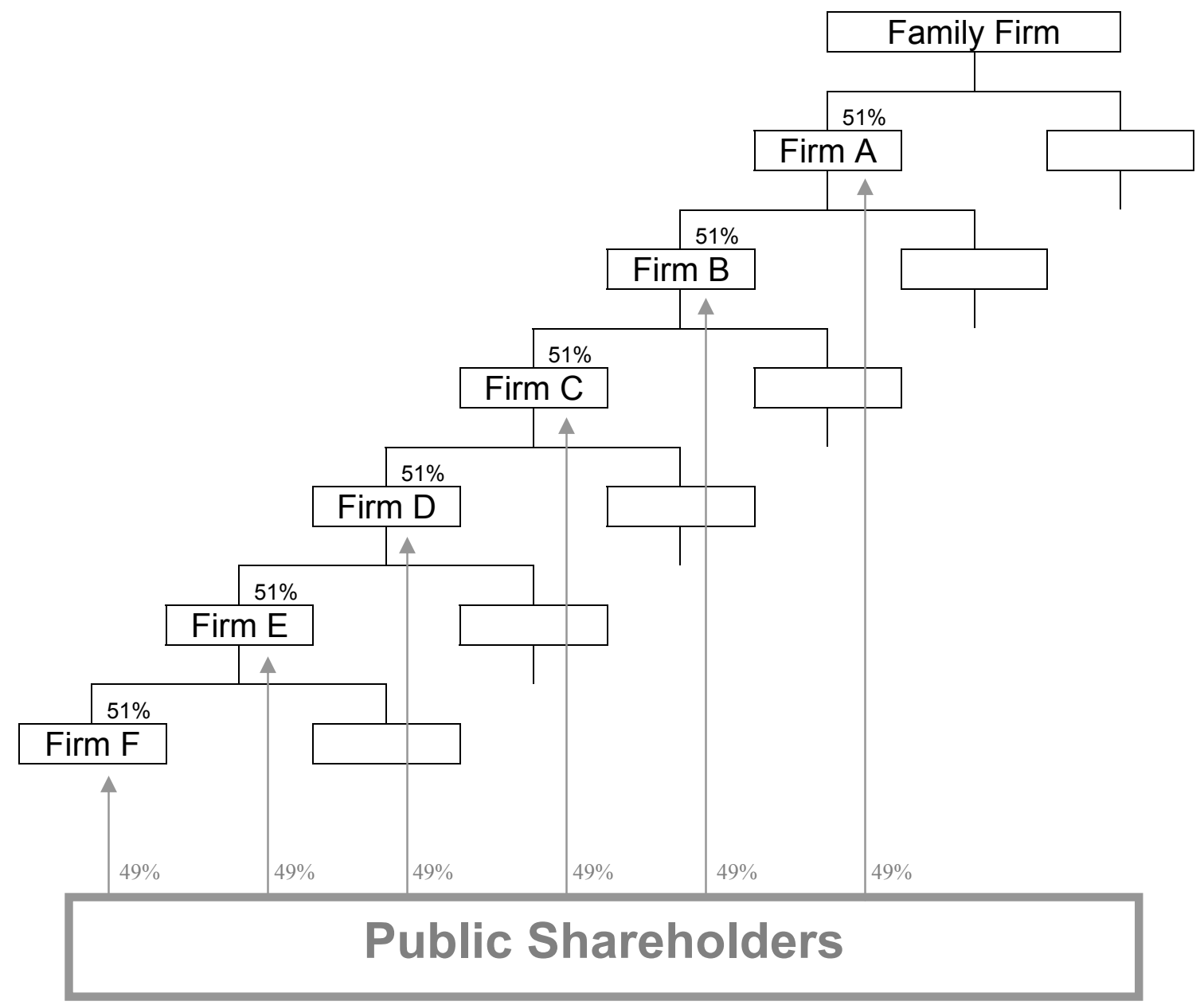

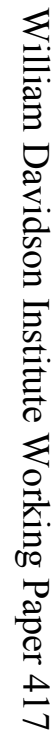




\section{DAVIDSON INSTITUTE WORKING PAPER SERIES - Most Recent Papers}

The entire Working Paper Series may be downloaded free of charge at: www.wdi.bus.umich.edu

CURRENT AS OF 12/17/01

\begin{tabular}{|c|c|c|}
\hline Publication & Authors & Date \\
\hline $\begin{array}{l}\text { No. 417: Capital Markets and Capital Allocation: Implications for } \\
\text { Economies in Transition }\end{array}$ & $\begin{array}{l}\text { Artyom Durnev, Randall Morck, } \\
\text { Kan Li and Bernard Yeung }\end{array}$ & Dec. 2001 \\
\hline $\begin{array}{l}\text { No. } 416 \text { Forthcoming in: The Journal of Economic Perspectives, "Data } \\
\text { Watch. Research Data from Transition Economies." }\end{array}$ & $\begin{array}{l}\text { Randall K. Filer and Jan } \\
\text { Hanousek }\end{array}$ & Dec. 2001 \\
\hline $\begin{array}{l}\text { No. } 415 \text { Forthcoming in: The Journal of Economic Perspectives, } \\
\text { "Transition Economies: Performance and Challenges." }\end{array}$ & Jan Svejnar & Dec. 2001 \\
\hline $\begin{array}{l}\text { No. } 414 \text { Forthcoming in: The Journal of Economic Perspectives, "The } \\
\text { Great Divide and Beyond: Financial Architecture in Transition." }\end{array}$ & Erik Berglof and Patrick Bolton & Dec. 2001 \\
\hline $\begin{array}{l}\text { No. } 413 \text { Forthcoming in: The Journal of Economic Perspectives, "The } \\
\text { Political Economy of Transition." }\end{array}$ & Gérard Roland & Dec. 2001 \\
\hline $\begin{array}{l}\text { No. 412: The Response of Consumption in Russian Households to } \\
\text { Economic Shocks }\end{array}$ & Steven Stillman & Oct. 2001 \\
\hline No. 411: Mark-ups in Hungarian Corporate Sector & László Halpern and Gábor Kőrösi & Aug. 2001 \\
\hline No. 410: Economic Development, Legality, and the Transplant Effect & $\begin{array}{l}\text { Daniel Berkowitz, Katarina } \\
\text { Pistor, Jean-Francois Richard }\end{array}$ & Sept. 2001 \\
\hline No. 409: Development Strategy, Viability, and Economic C & Justin Yifu Lin & Oct. 2001 \\
\hline No. 408: Labor Supply, Informal Economy and Russian Transition & Maxim Bouev & May 2001 \\
\hline No. 407: Corporate Governance in China: Then and Now & Cindy Schipani and Liu Junhai & Nov. 2001 \\
\hline No. 406: Entrepreneurship and Post-Socialist Growth & $\begin{array}{l}\text { Daniel Berkowitz and David N. } \\
\text { DeJong }\end{array}$ & Oct. 2001 \\
\hline $\begin{array}{l}\text { No. } 405 \text { Forthcoming in: European Economic Review, "Policy Reform } \\
\text { and Growth in Post-Soviet Russia." }\end{array}$ & $\begin{array}{l}\text { Daniel Berkowitz and David N. } \\
\text { DeJong }\end{array}$ & Oct. 2001 \\
\hline $\begin{array}{l}\text { No. 404: Social Policies and Structures: Institutional Frictions and Traps } \\
\text { in the Czech Republic after } 1989\end{array}$ & Jiří Večerník & Nov. 2001 \\
\hline $\begin{array}{l}\text { No. 403: Investment, Efficiency, and Credit Rationing: Evidence from } \\
\text { Hungarian Panel Data }\end{array}$ & Mathilde Maurel & Nov. 2001 \\
\hline $\begin{array}{l}\text { No. 402: Subduing High Inflation in Romania. How to Better Monetary } \\
\text { and Exchange Rate Mechanisms? }\end{array}$ & $\begin{array}{l}\text { Daniel Daianu and Radu } \\
\text { Vranceanu }\end{array}$ & Aug. 2001 \\
\hline $\begin{array}{l}\text { No. 401: The Gender Wage Gap in Bulgaria: A Semiparametric } \\
\text { Estimation of Discrimination }\end{array}$ & Dean Jolliffe & July 2001 \\
\hline $\begin{array}{l}\text { No. 400: Do External Auditors Perform a Corporate Governance Role in } \\
\text { Emerging Markets? Evidence from East Asia }\end{array}$ & Joseph P. H. Fan and T.J. Wong & Oct. 2001 \\
\hline $\begin{array}{l}\text { No. 399: Financial Conditions and Investment during the Transition: } \\
\text { Evidence from Czech Firms }\end{array}$ & Lubomír Lízal and Jan Svejnar & Oct. 2001 \\
\hline $\begin{array}{l}\text { No. 398: Accessible Pareto-Improvements: Using Market Information to } \\
\text { Reform Inefficiencies }\end{array}$ & Michael Mandler & May 2001 \\
\hline No. 397: The Making of an Integrated National Grain Market in China & Wubiao Zhou & Oct. 2001 \\
\hline No. 396: Corruption and Resource Allocation: Evidence from China & Wei Li & June 2001 \\
\hline $\begin{array}{l}\text { No. 395: Government Shareholding and the Value of China's Modern } \\
\text { Firms }\end{array}$ & Lihui Tian & Apr. 2001 \\
\hline No. 394: Labor Hoarding in Russia: Where Does it Come from? & $\begin{array}{l}\text { Rouslan Koumakhov and Boris } \\
\text { Najman }\end{array}$ & June 2000 \\
\hline $\begin{array}{l}\text { No. 393: Ownership Structure, Corporate Governance, And Firm Value: } \\
\text { Evidence from the East Asian Financial Crisis }\end{array}$ & Michael Lemmon and Karl Lins & Apr. 2001 \\
\hline No. 392: Marshall and Labour Demand in Russia: Going Back to Basics & $\begin{array}{l}\text { Jozef Konings and Hartmut } \\
\text { Lehmann }\end{array}$ & Aug. 2001 \\
\hline No. 391: Economic Transition and Elections in Poland & $\begin{array}{l}\text { John E. Jackson, Jacek Klich, and } \\
\text { Krystyna Poznańska }\end{array}$ & June 2001 \\
\hline
\end{tabular}

